\title{
Perspectives for immunotherapy in endocrine cancer
}

\author{
S Latteyer1,2, V Tiedje1,2, B Schilling ${ }^{3,4}$ and D Führer ${ }^{1,2}$ \\ 'Department of Endocrinology and Metabolism, University Hospital Essen, University of Duisburg-Essen, \\ Essen, Germany \\ 2Endocrine Tumour Center at West German Cancer Center (WTZ), Essen, Germany \\ ${ }^{3}$ Department of Dermatology, Venereology and Allergology, University Hospital Essen, University of Duisburg-Essen, \\ Essen, Germany \\ ${ }^{4}$ German Cancer Consortium (DKTK), Heidelberg, Germany
}

Correspondence

should be addressed

to $D$ Führer

Email

Dagmar.fuehrer@uk-essen.de

\begin{abstract}
The fight against cancer has seen major breakthroughs in recent years. More than a decade ago, tyrosine kinase inhibitors targeting constitutively activated signaling cascades within the tumor inaugurated a new era of oncological therapy. Recently, immunotherapy with immune checkpoint inhibitors has started to revolutionize the treatment of several malignancies, most notably malignant melanoma, leading to the renaissance and the long-awaited breakthrough of immunooncology. This review provides an overview of the basis of immunotherapy from its initial concepts of antitumor immunity and cell-based therapy to the development of immune checkpoint inhibitors and discusses published studies and the perspectives of immunooncology for the treatment of endocrine malignancies.
\end{abstract}

\author{
Key Words \\ - immunooncology \\ - immune checkpoint \\ blockade \\ - anti-CTLA-4 \\ - anti-PD-1 \\ - tumor microenvironment \\ - endocrine and \\ neuroendocrine cancer
}

Endocrine-Related Cancer (2016) 23, R469-R484

\section{Introduction}

For many years, the target of anticancer therapy was the tumor cell itself. This was supported by the perception that cancer is defined as autonomously proliferating cells and is the rationale for traditional chemotherapy. Subsequently, the identification of mutated oncogenes leading to constitutively activated signaling pathways within a tumor not only improved understanding of carcinogenesis but led to the development of targeted therapies, in particular tyrosine kinase inhibitors (TKIs). TKIs have indeed changed treatment of cancers in which chemotherapy was ineffective, including endocrine malignancies such as radioiodine refractory thyroid cancer (Brose et al. 2014, Schlumberger et al. 2015), medullary thyroid cancer (MTC) (Wells et al. 2012, Elisei et al. 2013) and neuroendocrine tumors of the pancreas (Kulke et al. 2008, Raymond et al. 2011). TKIs counteract tyrosine kinase signaling, for example through RET, EGFR, MET, VEGFR, BRAF and PI3K/AKT and usually affect multiple pathways. The extent to which the benefits of TKIs are due to their effect on tumor signaling per se, or are due to anti-VEGF effects that shut down tumor vasculature, is still a matter of debate. Either way, TKIs confer disease stabilization or at best partial response but do not allow for cure of solid cancers (Levitzki 2013).

In addition, the concept of an exclusive oncogene addiction of cancer has been challenged by evidence that tumour cells are in perpetual interaction with their microenvironment, also termed the 'tumor stroma'. The tumor stroma describes the non-cancerous cells present in or adjacent to the tumor and in principle consists of distinct mesenchymal cells, tumor vessels, extracellular matrix and immune cells (Fig. 1)

Published by Bioscientifica Ltd. 


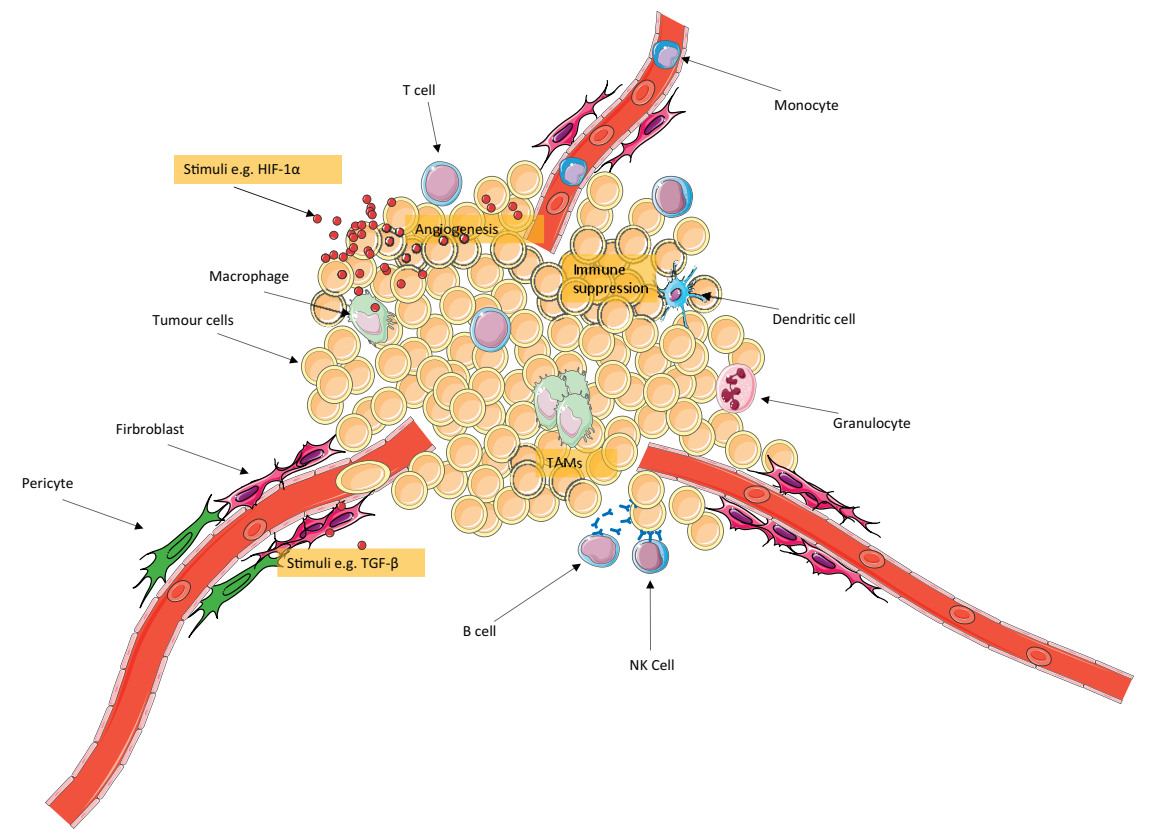

\section{Figure 1}

Scheme of tumor microenvironment containing tumor cells, tumor vessels, pericyte support fibroblast and cells of innate and adaptive immune system. HIF-1 $\alpha$, hypoxia-inducible factors; TAMs, tumor-associated macrophages; TGF- $\beta$, transforming growth factor- $\beta$.
(Klement 2016). In this microenvironment, the tumor gains 10 characteristic features that were defined by Hanahan and Weinberg as 'The Hallmarks of Cancer' (Hanahan \& Weinberg 2000, 2011): (i) resisting cell death, (ii) sustaining proliferative signaling, (iii) evading growth suppressors, (iv) enabling replicative immortality, (v) inducing angiogenesis, (vi) activating invasion and metastasis, (vii) deregulation of cellular energetics, (viii) genome instability and mutation, (ix) tumor-promoting inflammation and (x) avoiding immune destruction.

In recent years, researchers have focused on dissecting components of this interplay, in particular the role of the immune system. These studies have led to the development of immunotherapies that may induce, enhance or suppress an immune response against cancer cells. Decades ago, the first concepts were developed to reach these goals, for example with IL-2 (Pizza et al. 1988), IL-7 (Moller et al. 2000) or interferons (VadhanRaj et al. 1986); with activating immunotherapy, for example by T-cell adoptive transfer (Curti et al. 1993) or dendritic cell (DC) vaccination (Gjertsen et al. 1996) or alternatively with suppressive immunotherapy, for example by glucocorticoids (Vietti et al. 1965). In this review, we will briefly introduce these concepts and the role of immune checkpoint inhibitors, which are currently recognized as a major breakthrough in immunooncology, before we review the published literature on immunoenvironment and immunotherapy in endocrine cancers (Table 1).

\section{Initial concepts of immunotherapy using antibodies directed against cancer cells}

In immunomodulation, an antibody is directed against the tumor cell itself, conferring apoptosis or antibody-dependent cellular cytotoxicity (ADCC). This kind of monoclonal antibody is designed to bind to a specific surface molecule, for example a tumorassociated antigen to ensure tumor-specific effects. The first antibody used to treat cancer, rituximab (Mabthera), was approved by the US Food and Drug Administration (FDA) in 1997. Rituximab is a specific CD20 antibody, targeting CD20+ B cells in leukemia and malignant lymphoma. The FDA approval of rituximab was followed by the approval of denileukin diftitox (Ontak) for targeting cutaneous $\mathrm{T}$ cells 2 years later. Denileukin diftitox is a fusion protein in which the native receptor-binding domain of diphtheria toxin is replaced by the full-length interleukin-2 (IL2 ). This modification allows binding of the drug to IL-2-R expressing T cells (especially the $\alpha$-chain of the receptor (CD25)), introduction of diphtheria toxin into the cells and consequently induction of apoptosis. Preclinical and clinical studies indicate that stage IV melanoma patients might benefit from depletion of regulatory $\mathrm{T}$ cells (Treg) (Mahnke et al. 2007, Telang et al. 2011). However, effects of denileukin diftitox did not correlate with CD25 expression and Treg depletion was not confirmed unambiguously (Attia et al. 2005). The major disadvantage of this and other early drugs designed for similar targets was their lack of specificity

Published by Bioscientifica Ltd 
Table 1 Literature on tumour microenvironment and immunotherapy in endocrine/neuroendocrine cancers.

\begin{tabular}{l} 
Tumour \\
\hline PTC, fvPTC, tcPTC, FTC \\
(minimal and widely \\
invasive), FA, nodular \\
goiter, normal tissue \\
PTC, fvPTC, tcPTC, FTC \\
(minimal and widely \\
invasive), FA, nodular \\
goiter, normal tissue \\
PTC, autoimmune \\
thyroiditis
\end{tabular}

DTC, PDTC, ATC

FTC, FA

PDTC, ATC

PTC

PTC, ATC, normal tissue

GEP-NETs (distinct locations) PTC (inducible)

ATC

Pheochromocytoma

MTC

\begin{tabular}{lll}
\hline Model/tissue & & Technique \\
FFPE & IHC \\
FFPE & IHC, mRNA leve \\
$\begin{array}{l}\text { Frozen tissue } \\
\text { section }\end{array}$ \\
FFPE & IHC, microarray
\end{tabular}

FFPE

IHC

FFPE

NGS

FFPE

IHC

Human tissue microarray sections

Patients

Patients

Patients

FFPE

BRAFV600E mouse model

Genetically
engineered
murine ATC:
TBP 3743
BRAFV600E/WT
P53-I- cells were
implanted into
immuno-
competent
mouse thyroid
Mouse model

Genetically murine ATC: TBP 3743 immunomouse thyroid

Chromogranin A-based dendritic cell vaccination

Peptide-pulsed DC vaccination

Peptide-pulsed DC vaccination

Ex vivo generated granulocyte-macrophage colony-stimulating factor and interferon-alpha dendritic cells IHC

Intramuscular injection of mrlL-12 plasmid and and phenotyping of effector cells

tumour volume

\section{Result}

TAM increases with dedifferentiation

Literature

Cunha et al. (2012)

Cunha et al. (2013)

D-L1 expression correlates with higher CD4+, CD8+, CD20+ and FoxP3+ lymphocyte content and TAM infiltrate

CD3+, CD4- and CD8- were significantly more abundant in thyroid cancer compared to thyroid autoimmunity

TAM density increased in advanced thyroid cancers and correlated with invasion and decreased patient survival

Higher density of TAMs increases chemokine CCL15

Macrophage gene expression pattern was sufficient to discriminate ATC from PDTC

BRAFV600E tumours express high levels of PD-L1 (53\% vs $12.5 \%$ ) compared to BRAF WT tumours, no significant difference in TAM pattern was observed

ATCs had the highest density of CD163-positive macrophages

$(22.9 \pm 17.1 \%)$, PTC the lowest CD163-positive macrophage density $(1.8 \pm 1.3 \%)$ intraperitoneal injection of mrIL-12, IHC, NK cell assay

Response rate $3 / 7$ patients

Schott et al. (2001)

Response rate $3 / 10$ patients

Response rate $2 / 5$ patients

Bachleitner-Hofmann et al. (2009)

Papewalis et al. (2008)

PD-L1 is a negative prognostic factor in GEP-NETs

Significantly lower tumor burden mediated by CD8+ and natural killer cells

Combined treatment of BRAFinhibitor and PD-L1 antibody (baseline: $782.3 \pm 174.6 \mathrm{~mm}^{3}$ vs $439.3 \pm 188.4 \mathrm{~mm}^{3}$ (BRAF inhibitor) and $716.7 \pm 62.1 \mathrm{~mm}^{3}$ (PD-L1) to $147.3 \pm 60.8 \mathrm{~mm}^{3}$ with BRAF inhibitor/ PD-L1 combination) was more efficient than single treatments

Chromogranin A vaccinated mice show a large amount of infiltrating CD8+ cells and reduction of liver metastases
Kim et al. (2016)

Parhar et al. (2016)

Brauner et al. (2016)

Papewalis et al. (2011)

ATC, anaplastic thyroid cancer; FA, follicular adenoma; FFPE, formalin fixed paraffin embedded tissue; FTC, follicular thyroid cancer; fvPTC, follicular variant PTC; GEP-NET, gastrointestinal pancreatic neuroendocrine tumours; IF, immunofluorescence; IHC, immunohistochemistry; MTC, medullary thyroid cancer; PDTC, poorly differentiated thyroid cancer; PTC, papillary thyroid cancer; tcPTC, tall cell PTC. 
resulting in an increasing number of severe adverse events (AEs), including a black box warning in some cases. Once TKI emerged, the number of trials exploring this approach for solid malignancies decreased. Nevertheless, immunomodulation continues to play a role in the treatment of hematological malignancies: breast (anti-HER2), colorectal and head and neck cancer (cetuximab).

\section{Cell-based therapies}

Effective anti-tumor immunity is based on the existence of a repertoire of the so-called 'autoreactive' $\mathrm{T}$ and $\mathrm{B}$ cells. When these cells are properly activated, they can recognize malignant cells, which express tumor-associated antigens (Coulie et al. 2014).

Adoptive T-cell transfer of tumor-infiltrating lymphocytes (TILs) is a cell-based immune therapy and involves ex vivo expansion of specific effector cells. Pilot studies for ex vivo expansion of TIL were already done in the 1980s in melanoma, renal cell, breast and colon carcinoma patients, and indicated that melanoma is a more immune-sensitive cancer than others (Topalian et al. 1988). Efficiency of TIL therapy can be enhanced by applying IL-2 to the patients. Preparative lymphodepleting chemotherapy of melanoma patients followed by high-dose IL-2 in combination with TIL conferred a $50 \%$ response rate in clinical trials and it seemed that a subset of patients has durable benefit from this treatment (Dudley et al. 2005, Besser et al. 2010, Wu et al. 2012). TIL therapy, per se, causes minor side effects, but in combination with IL-2 severe AEs were observed such as hypotension, diarrhea, chills, vomiting, nausea, confusion and vascular leak syndrome (Dreno et al. 2002, Kradin et al. 1989, Rosenberg et al. 1989). TIL therapy is a laborious, personalized approach, which cannot be applied off-the-shelf and hence it is currently only explored in clinical trials.

DC-based vaccination follows a different proactive route of cancer treatment. In DC vaccination, it is possible to use a multipeptide vaccination cocktail against several antigens in vivo. If DC takes up and processes those peptides, it is possible to prime a larger number of specific lymphocytes with a diverse T-cell receptor (TCR) repertoire (Jeanbart \& Swartz 2015). Thus, the principle of DC vaccination is to 'teach' the immune system to kill tumor cells that express specific peptides or cocktails of peptides on their surface. Researchers focusing on this approach have to meet several challenges: One problem is to find immunogenic peptides expressed only on the surface of the tumor cells to avoid adverse effects in the periphery. Another challenge is the effective and fast priming of effector cells in vivo. So far, no randomized clinical trial has been able to show efficacy of a DC-based vaccine (Yi \& Appel 2013), however, combinational usage of DC could be a promising future perspective. Recently, a first randomized phase II trial was launched to test DC vaccination in combination with TKI (Dasatinib) treatment in metastatic melanoma patients (NCT01876212). Results of this trial are awaited by July 2018 .

\section{Immune checkpoint inhibitors: the milestone in immunooncology}

Immune evasion mechanisms are crucial for tumor cell survival (Hanahan \& Weinberg 2000, 2011). The pivotal role of CTLA-4 (Leach et al. 1996) and subsequently of programmed death receptor-1 (PD-1)/PD-L1 (Dong et al. 2002) in that respect has led to the development of antibodies against these molecules. These antibodies, the so-called 'immune checkpoint inhibitors', have inaugurated a new era of cancer treatment (Melero et al. 2015, Topalian et al. 2015).

CTLA-4 is expressed on the surface of helper, cytotoxic and regulatory $\mathrm{T}$ cells, and is a member of the immunoglobulin superfamily. CTLA- 4 is, similar to CD28, a T-cell co-stimulatory protein. Both are able to bind to B7 family members, which are expressed on antigen-presenting cells (APCs). While CD28 ligation is a co-stimulatory signal for TCR activation, CTLA- 4 binding results in T-cell inhibition (Fig. 2). In vivo, TCR binding leads to upregulation of CTLA-4, which has a higher affinity to B7 molecules than CD28. By adding a CTLA-4 antibody as a checkpoint inhibitor the negative feedback is decreased and the T-cell cytotoxic response augmented (Fig. 2) (Walunas et al. 1994, Krummel \& Allison 1995, Waterhouse et al. 1995, Walunas et al. 1996).

In vivo experiments in rodents demonstrated that anti-CTLA-4 therapy leads to reduction in size of several types of cancer, such as colon (Leach et al. 1996, Son et al. 2014), renal (Lan et al. 2013) and prostate cancer (Kwon et al. 1997, Li et al. 2014) and lymphoma (Shrikant et al. 1999, Sotomayor et al. 1999). Treatment with the anti-CTLA-4 antibody ipilimumab (Yervoy, BristolMyers Squibb, Princeton, NJ, USA) showed a significant benefit for overall survival in patients with advanced melanoma (Table 1) (Hodi et al. 2010, Robert et al. 2011). In a pooled analysis of more than 1800 patients with a follow-up period of up to 10 years, it was shown that ipilimumab leads to long-term survival in about $20 \%$ of

Published by Bioscientifica Ltd 


\title{
Lymph Node
}

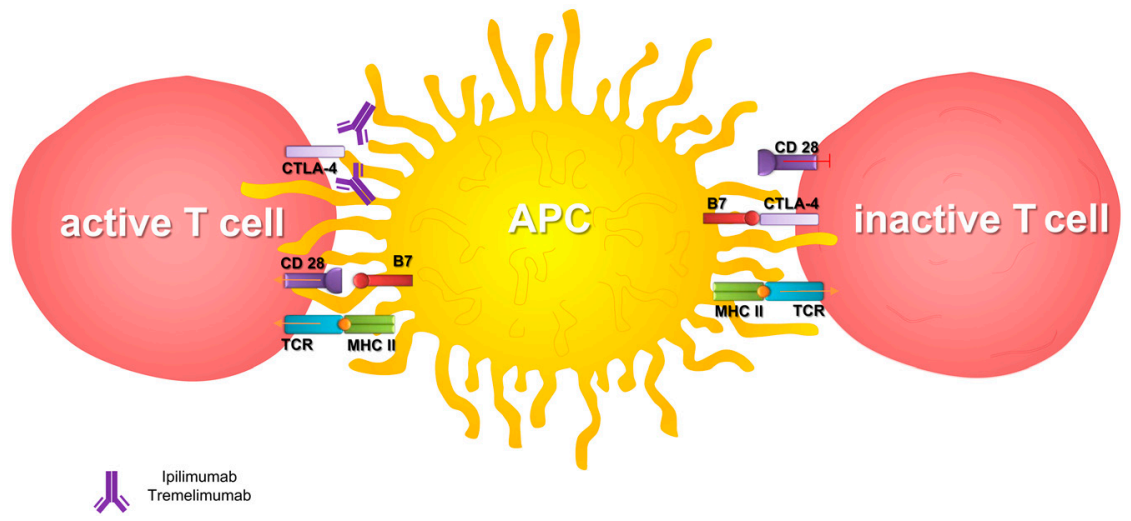

\begin{abstract}
Figure 2
T-cell activation in a lymph node after antigen presentation by APC via TCR/MHCIl complex and Co-stimulatory signal B7. Right: CTLA-4 binding to $B 7$ together with TCR complex results in T-cell inactivation. Left: Anti-CTLA-4 antibodies block the interaction of CTLA-4 and B7 and thereby confer T-cell activation. MHC, major histocompatibility complex; TCR, T-cell receptor.
\end{abstract}

melanoma patients (Schadendorf et al. 2015). Ipilimumab was the first checkpoint inhibitor to be approved by the FDA in 2011 for unresectable stage III or metastatic stage IV melanoma and subsequently as adjuvant therapy for highrisk stage III melanoma in 2015 (Eggermont et al. 2015).

AEs related to anti-CTLA-4 treatment are frequent and include immune-related endocrinopathies, notably hypophysitis (Yang et al. 2007), adrenalitis (Yang et al. 2007) and thyroiditis (Blansfield et al. 2005, Dillard et al. 2010, Min et al. 2011, Corsello et al. 2013, Ryder et al. 2014), in addition to other immune-related AE such as colitis (Royal et al. 2010), hepatitis and uveitis (Hodi et al. 2014).

PD-1 is a cell surface molecule closely related to CTLA-4 and is part of the CD28 family. PD-1 inhibits immune response by preventing T-cell activation (Ishida et al. 1992). B cells, T cells, monocytes, natural killer cells and TILs express PD-1 on their surface. PD-1 interacts with two known ligands: PD-L1 and PD-L2 (Latchman et al. 2001). PD-L1 expression was initially reported on melanoma, ovarian, colon and lung cancer cells (Dong et al. 2002) but can also be found in other human cancers such as breast (Baptista et al. 2016), head and neck (Malm et al. 2015) and pancreatic cancer (Bigelow et al. 2013). Interaction of PD-1 with PD-L1 has been conceived to act as an immune evasion mechanism for tumor cells (Dong et al. 2002, Iwai et al. 2002, Wu et al. 2006). Interestingly, antitumor immunity itself seems to drive PD-L1 expression on cancer cells (Spranger et al. 2013). Antibodies interrupting PD-1/PD-L1 interaction (Fig. 3) such as nivolumab (anti-PD-1, Bristol-Myers Squibb), pembrolizumab (anti-PD-1, MSD Merck, Whitehouse Station, NJ, USA) and atezulizumab (anti-PD-L1, Roche/ Genentech, Basel, Switzerland) have recently been approved for the treatment of advanced melanoma, nonsmall cell lung cancer, advanced bladder cancer, Hodgkin lymphoma and metastatic renal cell carcinoma (Table 2). PD-1/PD-L1 antibodies are surprisingly well tolerated with mostly CTCAE grade I or II AE-like rash, itching and fatigue making their application particularly attractive

\section{Tumour Microenvironment}

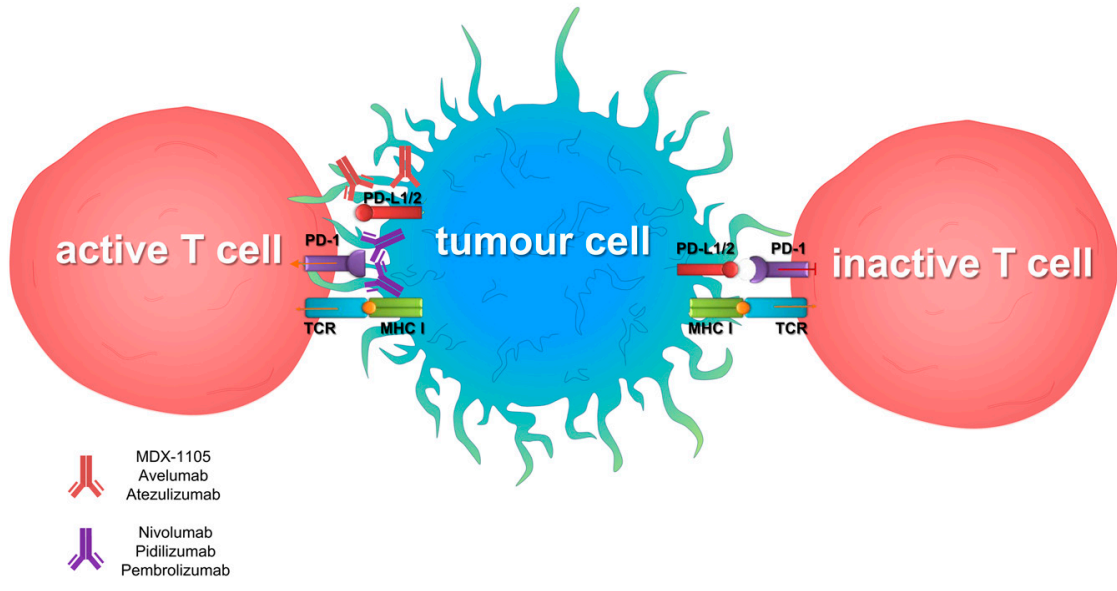

Figure 3

Interaction of T cells with tumor cells within the tumor microenvironment. Right: Tumor cells expressing PD-L1/2 are able to inactivate T cells via PD-1 pathway. Left: Tumor cells lose this ability when PD-1 and/or PD-L1/2 are blocked by antibodies and an appropriate T-cell response occurs resulting in killing of tumor cells. MHC, major histocompatibility complex; TCR, T-cell receptor. 

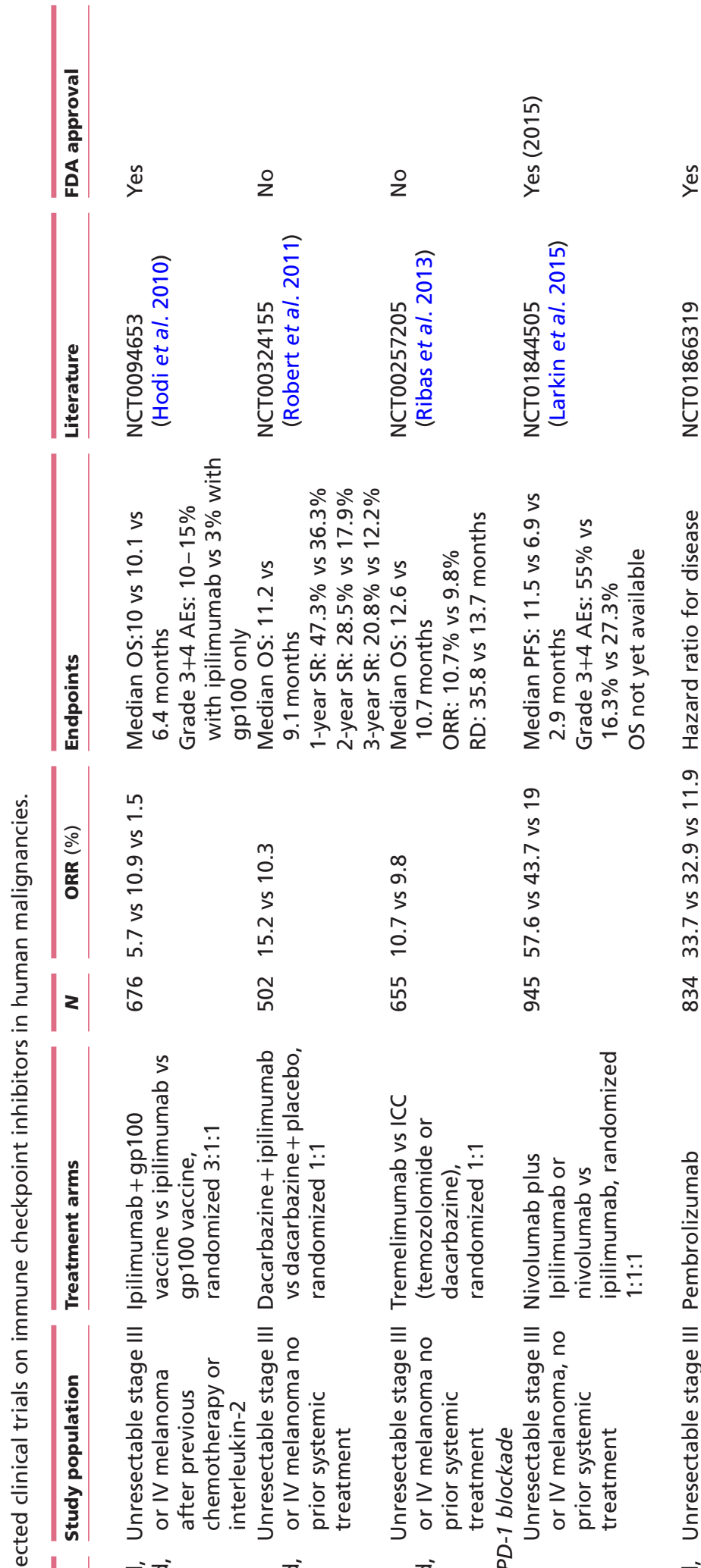

๖ั

$\stackrel{\square}{x}$
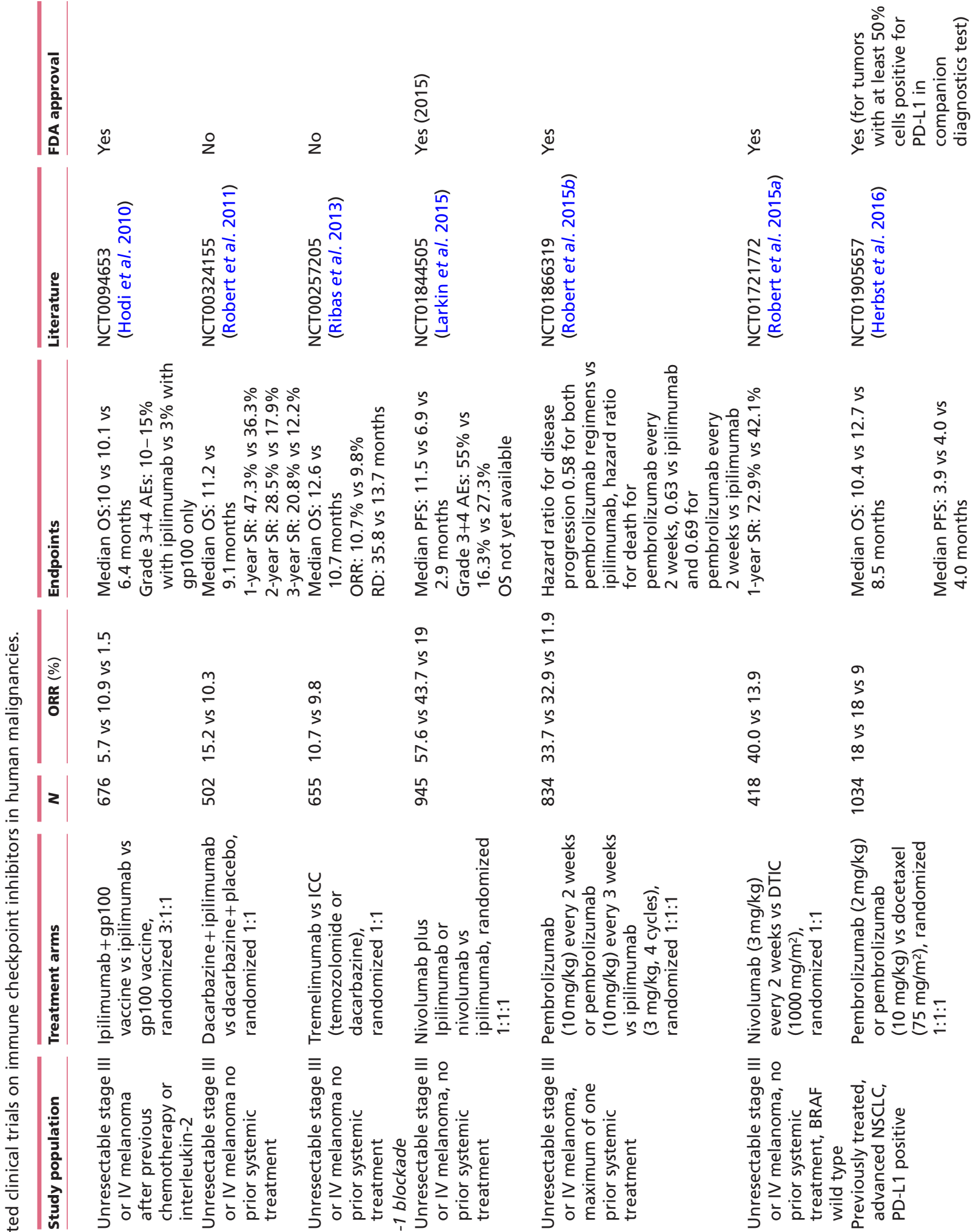

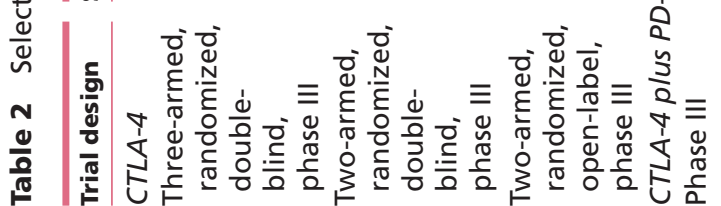

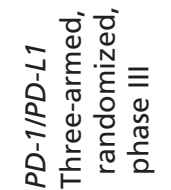
http://erc.endocrinology-journals.org
DOI: 10.1530/ERC-16-0169
(C) 2016 Society for Endocrinology Printed in Great Britain 

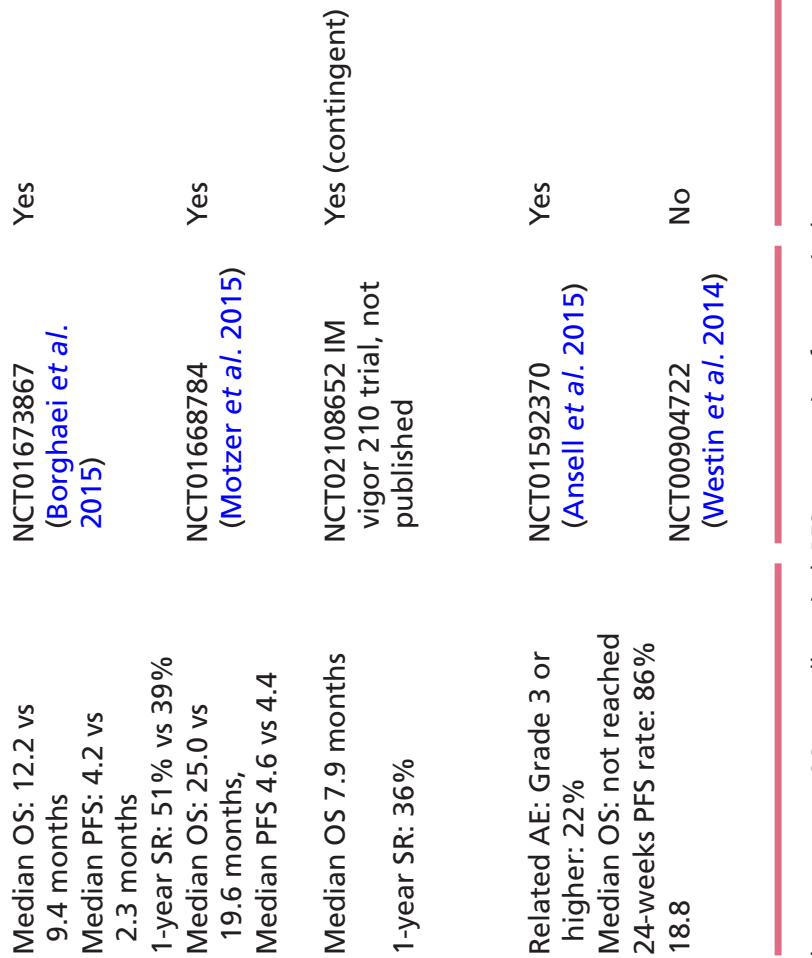

2
$\frac{2}{5}$
2
$\infty$
$\infty$
in

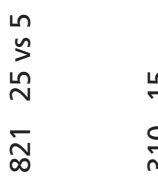

$\widehat{\infty}$

$\bullet$

$\stackrel{n}{N}$

$\tilde{m}$
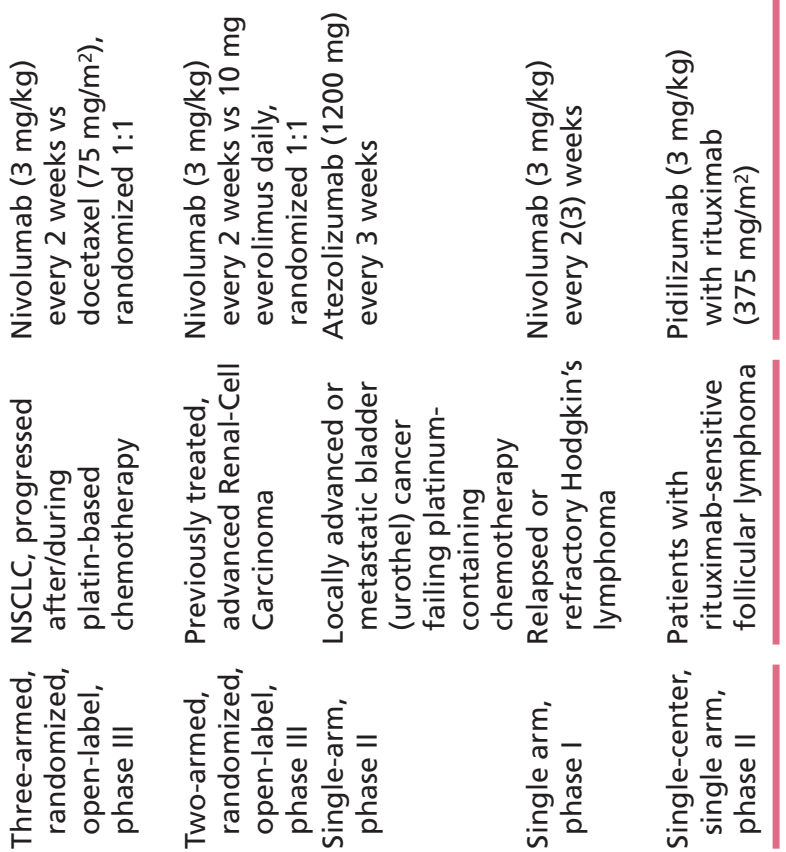

(Hofmann et al. 2016, Zimmer et al. 2016). In about $10-15 \%$ of patients receiving these antibodies, higher grade AEs such as colitis, hepatitis and pneumonitis do occur.

Little is known so far on PD-L2 function, except that it is expressed on the surface of DCs, macrophages, mast cells and B lymphocytes (Topalian et al. 2012). PD-L2 is upregulated in follicular B-cell lymphoma, Hodgkin lymphoma and primary mediastinal B-cell lymphoma (Rosenwald et al. 2003). Recent research could also identify an overexpression of PD-L2 in more than 50\% of breast cancer samples (Baptista et al. 2016) and esophageal squamous cell carcinoma but no correlation was found with disease-free survival and/or overall survival (Leng et al. 2016). So far, no therapeutics directly target PD-L2.

Recently, results of a randomized, double-blind, phase III head-to-head study were published comparing nivolumab (anti-PD-1) and ipilimumab (anti-CTLA-4) alone or in combination with previously untreated stage IV melanoma patients. Combination therapy resulted in significantly longer progression-free survival (PFS) (11.5 months) compared with nivolumab (6.9 months) or ipilimumab (2.9 months) monotherapy (Larkin et al. 2015). Unfortunately, severe grade 3 or $4 \mathrm{AE}$ occurred in the combination treatment arm in 55\% of patients, illustrating the narrow gap between effective anti-tumor response and unwanted side effects. However, several trials are currently exploring the use of combined immune checkpoint inhibitors (Antonia et al. 2016a,b) or the combination of immune checkpoint inhibitors together with other anticancer drugs such as chemotherapy or TKI (listed in Table 2) and the results of these will provide important information on how to best achieve antitumor treatment with tolerable side effects.

As immune checkpoint inhibitors do not appear to work for all cancers, with adenocarcinoma of the pancreas being a prominent example of lack of response (Royal et al. 2010), one crucial and also economically relevant issue is to define biomarkers that will predict response to checkpoint inhibitor therapy. Currently, response to immunotherapy seems to be dependent on various determinants, which indicates that a single predictive biomarker for successful immunotherapy of cancer is unlikely to be defined (Blank et al. 2016). Several studies have shown a correlation of tumor PD-L1 expression and response to anti-PD-1/ PD-L1 treatment (Herbst et al. 2014, Borghaei et al. 2015, Garon et al. 2015, Weber et al. 2015), whilst others did not (Larkin et al. 2015, McDaniela 2015, Robert et al. 2015b). Furthermore, one methodological problem using PD-L1 as a single biomarker might be that different antibodies are

Published by Bioscientifica Ltd 
used for immunohistochemistry (IHC) including but not limited to clones 28-8, 22C3, SP142, SP263, 5H1, MIH1 and 405.9A11. Furthermore, membrane and cytosolic staining for PD-L1 have to be distinguished (Joseph Grosso 2013, Angell et al. 2014, Robert et al. 2015a,b). In addition, harmonization of IHC protocols and definition of reliable cut-offs for quantification of PD-L1 staining is still missing with most tests focusing on PD-L1 expression on tumor cells (Borghaei et al. 2015) while others also include myeloid cells (Herbst et al. 2014). An additional challenge with analysis of PD-L1 expression is that the pattern may be dynamic due to adoption and interplay of tumor cells and their microenvironment, which may change with tumor evolution and progression (Fusi et al. 2015).

In the melanoma setting, apart from PD-L1 expression in the tumor microenvironment, density of CD8+ T-cell infiltrates has been found to be associated with clinical benefit from PD-1 blockade (Tumeh et al. 2014). Moreover, it was recently reported that high relative eosinophil count $(>1.5 \%)$, high relative lymphocyte count $(>17.5 \%)$ and low serum lactate dehydrogenase $(<2.5 \times$ elevation) were associated with response to pembrolizumab in melanoma patients (Weide et al. 2016) and a similar association has also been described for ipilimumab (Martens et al. 2016). In melanoma patients, these biomarkers may help to guide treatment decision, in particular as in BRAFV600E positive tumors, first-line therapy could involve either MAPK inhibitors (Larkin et al. 2014, Long et al. 2014) or a checkpoint inhibitor (Larkin et al. 2015, Robert et al. 2015b). An excellent overview of potential biomarkers predicting response to checkpoint inhibitor therapy has recently been published by Manson et al. (2016).

In addition, genetic alterations within the tumors also need to be considered. Overall, mutational load has been found to be associated with benefit from immune checkpoint blockade in melanoma and squamous cell lung cancer (Rizvi et al. 2015, Van Allen et al. 2015), especially when mutations were clonal (McGranahan et al. 2016). This finding can be explained by somatic mutations giving rise to the so-called neoantigens that act as tumor antigens. Hence, highly mutated tumors do look more foreign to the autologous immune system and are more prone to be recognized by $\mathrm{T}$ cells (Schumacher \& Schreiber 2015). This reasoning is also sustained by Champiat et al. in their meta-analysis of checkpoint inhibitor trials and treatment outcomes, which were correlated with the degree of genomic instability in the tumor. Based on this analysis they proposed that 'high levels of mutational heterogeneity and thus genomic instability in the tumor could be the key for success of immune checkpoint therapies' (Champiat et al. 2014).

\section{Imaging of oncological patients undergoing immunotherapy: immune-related response criteria}

While the response evaluation criteria in solid tumors (RECIST) are an internationally accepted tool to determine tumor response (Eisenhauer et al. 2009), these criteria were developed when oncologic treatments directly targeted proliferating tumor cells. With immunotherapy, however, objective response often manifests after initial tumor mass increase, due to immune cell infiltration, often called pseudo-progression, or the appearance of new lesions. Therefore, application of RECIST criteria might underestimate the therapeutic benefit of checkpoint inhibitors (Wolchok et al. 2009). In 2009 immune-related response criteria were first proposed for ipilimumab therapy in malignant melanoma patients (Wolchok et al. 2009) and were subsequently evaluated also for pembrolizumab treatment (Hodi et al. 2016). This issue has also been discussed in neurooncology (Okada et al. 2015) and for non-small cell lung cancer (Socinski 2015). A comprehensive overview of the application and relevance of immune-related response criteria is given by Hoos et al. (2015).

\section{Is there a role for immunotherapy in endocrine malignancy?}

Endocrine tumors originate from cells that secrete hormones into the bloodstream and by this can cause serious illness as illustrated in patients with Cushing's disease, acromegaly or Hedinger syndrome. With few exceptions, endocrine malignancies are slowly proliferating cancers where TKI treatment results in disease stabilization or at best partial response. Classical chemotherapies that induce DNA damage and stop cells' ability to grow and divide are, therefore, not very effective. Cancer cells with slow accumulation of mutations may have a higher chance in successfully evading the immune system (Corthay 2014).

\section{Thyroid cancer}

A successful immune response depends largely on the recruited immune cells within the tumor. In recent years, different groups have characterized the immune microenvironment in thyroid cancer.

Cunha et al. analyzed samples of 398 patients with thyroid tumors (follicular thyroid carcinoma (FTC),

Published by Bioscientifica Ltd 
papillary thyroid carcinoma (PTC), FA) and normal tissues by IHC (Cunha et al. 2012). Tumor-associated macrophages (TAMs) were found in malignant (82.11\%) and less frequently in benign thyroid tumors (33.91\%). This may suggest that macrophages might be important in the context of thyroid cancer. Macrophages are part of the innate immune system and are divided into different subpopulations. The classically activated M1 macrophages are usually induced by proinflammatory signals (e.g. LPS), whereas M2 macrophages are activated due to wound healing or tissue repair, mainly by IL-4 and IL-13. TAMs are a subpopulation of macrophages that share both features and, therefore, are M1- and M2-like. TAMs are reported to possess pro- and antitumoral activity. Typical markers for TAMs are the cell surface proteins CD68 and CD163. Whereas CD68 (glycoprotein) is a relatively nonspecific marker for monocyte/ macrophage lineage in melanoma, lymphoma and schwannoma (Nguyen et al. 2005), CD163 (hemoglobin scavenger receptor) has been shown to be highly specific for monocyte/macrophage lineage in the tumor (Nguyen et al. 2005, Harris et al. 2012).

Ryder et al. showed that the density of TAMs in human samples correlates with thyroid dedifferentiation. Thus, macrophage density increased from $27 \%$ in differentiated thyroid cancers to $54 \%$ in poorly differentiated thyroid cancer (PDTC) and reached 95\% in anaplastic thyroid cancer (ATC). Furthermore, it was shown that high density of TAMs correlates with capsular invasion, extra-thyroidal extension and decreased cancer-related survival compared with low-density TAM concentrations in PDTC (Ryder et al. 2008). Similar results were reported by Jung et al. investigating the density of CD163+ macrophages in ATC $(22.9 \pm 17.1 \%$, $N=18)$ and PTC $(1.8 \pm 1.3 \%, n=35)$ (Jung et al. 2015). In a recent landmark paper on the genomic signature of PDTC and ATC, Landa et al. showed that 68 out of 78 investigated M2 macrophage genes were overexpressed in PDTC and ATC samples. Importantly, the authors report that the presence of macrophage infiltration was sufficient to even discriminate ATCs from PDTCs (Landa et al. 2016). Still the question remains: which mechanisms lead to macrophage recruitment? In this respect, Huang et al. studied FTC and FA samples and observed a higher density of TAMs in FTC (density of CD68+ cells $9.5 \pm 5.4 /$ field) compared with follicular adenoma ( $4.9 \pm 3.4 /$ field), which correlated with increase of chemokine mRNA CCL15 (51-fold) expression and CCL15 immunostaining (68\% in FTCs compared with $23 \%$ in FAs) (Huang et al. 2015).
In a recent study Cunha et al. also investigated PD-L1 expression in thyroid cancer (253 PTC, 40 FTC) and 114 benign thyroid tissues ( 58 nodular goiters and 56 follicular adenomas) and found that PD-L1 is expressed in 78.4\% of goiters, $84.3 \%$ of follicular adenomas, $82.5 \%$ of PTCs and $87.5 \%$ of FTCs. No correlation was observed between PD-L1 expression and tumor size or cancer aggressiveness. However, higher expression of PD-L1 correlated with significant increase of $\mathrm{CD} 4+\quad(P=0.04942), \quad \mathrm{CD} 8+$ $(P=0.0003), \mathrm{CD} 20+(P=0.01283)$, FoxP3 $+(P=0.00626)$ lymphocytes and TAMs $(P<0.0001)$ in the respective tumor samples. Interestingly, decreased PD-L1 expression was found in thyroid cancer lymph node metastases (Cunha et al. 2013).

Angell et al. studied 33 PTC for correlation between $B R A F$ mutation status and PD-L1 expression using IHC and found that presence or absence of the BRAFV600E mutation was associated with PD-L1 overexpression (53\% BRAFV600E (positive) vs $12.5 \%$ BRAFV600E (negative)) and lower CD8+ effector to FoxpP3+ regulatory T-cell ratios $(8.67 \pm 2.23$ vs $30.32 \pm 8.84$, respectively $(P<0.05))$. In contrast, BRAFV600E positivity had no impact on TAM (CD68+ or CD163+ positive macrophages) content in PTCs (Angell et al. 2014). This observation leads to the hitherto unresolved question whether mutational features and/or load (e.g. RET, RAS, ALK, etc.) in thyroid cancer cells may correlate with PD-L1 overexpression.

Further aspects of the immune microenvironment of the thyroid gland were described by Imam et al. Challenging the notion that autoimmune thyroiditis and PTC may be linked, they compared the tumor-associated lymphocyte pattern in PTC $(n=11)$ with lymphocytes found in autoimmune thyroiditis $(n=7)$. Based on investigation of frozen tissue sections and flow cytometry (Imam et al. 2014), they showed that CD3+, CD4- and CD8- lymphocytes were significantly more abundant in PTC $(>20 \%)$ compared with autoimmune thyroiditis $(<5 \%)$. Moreover, after PMA/Ionomycin stimulation, the population of $\mathrm{CD} 3+, \mathrm{CD} 4-$ and CD8- lymphocytes derived from PTC patients remained unchanged, but increased in samples derived from thyroid autoimmunity patients. Furthermore, CD25 ( $\alpha$-chain of the IL-2 receptor and marker for activation) expression on $\mathrm{CD} 3+$ and CD4+ did not change after stimulation in PTC and thyroid autoimmunity patients, leading the authors to conclude that the expansion of total numbers of $\mathrm{CD} 3+, \mathrm{CD} 4-$ and CD8- lymphocytes in thyroid autoimmunity was at the expense of inactivation of single positive T cells.

One reason for the increase of $\mathrm{CD} 3+, \mathrm{CD} 4-$ and CD8- lymphocytes in PTC might be loss of CD4 and

Published by Bioscientifica Ltd 
CD8 expression. This could indicate that CD3+, CD4and CD8- lymphocytes play a role in downregulation of proliferation and cytokine production of activated effector T cells within the tumor microenvironment and may thereby play a crucial role in immune tolerance.

Various thyroid cancer mouse models have been developed in recent years including the inducible BRAFV600E mouse for PTC (Knauf et al. 2005) or an orthotopic mouse model for FTC (Greco et al. 2016). In such mouse models, it is now possible to evaluate the efficacy of immune checkpoint inhibitors and combined therapies for treatment of aggressive thyroid cancer. This approach has recently been shown to result in dramatically improved tumor regression under combined BRAF inhibitor and PD-L1 antibody treatment (baseline: $782.3 \pm 174.6 \mathrm{~mm}^{3} \mathrm{vs}$ $439.3 \pm 188.4 \mathrm{~mm}^{3}$ (BRAF inhibitor) and $716.7 \pm 62.1 \mathrm{~mm}^{3}$ (PD-L1) to $147.3 \pm 60.8 \mathrm{~mm}^{3}$ with BRAF inhibitor/PD-L1 combination) (Brauner et al. 2016). In addition, a very recent study from Parhar et al. demonstrated the influence of IL-12 on immune response and tumor growth in BRAF ${ }^{\mathrm{V} 600 \mathrm{E}}$ mice. They compared intramuscular injection of recombinant mouse IL-12 plasmid and intraperitoneal injection of recombinant mouse IL-12. Both treatments resulted in significantly lower tumor burden and were mediated by CD8+ and natural killer cells. Suppression of IL-12 abolished these effects indicating that IL-12 might be of interest as adjuvant therapy in advanced BRAFV600E thyroid cancers (Parhar et al. 2016).

With the help of these preclinical models, it will be possible to further phenotype and characterize the development and recruitment of immune cells during thyroid carcinogenesis and cancer progression as a prerequisite to define successful immunotherapy. In this respect, TAMs that show high expression of immunosuppressive cytokines (e.g. IL-10, TGFB1) may be attractive, but PD-1/PD-1L per se could be a suitable target as well. In addition, following the hypothesis of Champiat and coworkers and in view of the findings recently published by Landa and coworkers showing increased mutational load in PDTC and ATC, it is conceivable that immunotherapy may be useful in these most detrimental TC (Champiat et al. 2014, Landa et al. 2016).

\section{Clinical trials}

Immunotherapy for treatment of thyroid cancer was tested in pilot studies in few patients with MTC and advanced differentiated thyroid cancer. Schott et al. showed that calcitonin and/or carcinoembryonic antigen peptide pulsed DC resulted in a cellular antigenspecific immune response in some MTC patients (Schott et al. 2001). Similar results were obtained in a study by Bachleitner-Hofmann et al. (2009). Improvement of this technique led to ex vivo generated granulocytemacrophage colony-stimulating factor and interferonalpha DCs (IFN-DCs) that were injected into 5 patients. Two patients had an excellent response with a large increase of antigen-specific IFN-gamma-secreting CD4+ cells and CD8+ cells with increase of granzyme B in the peripheral blood. Interestingly, a decrease of CD4+, $\mathrm{CD} 25+$ and FoxP3+ regulatory $\mathrm{T}$ cells was observed (Papewalis et al. 2008). Wuttke et al. used a mouse model (Ret/Cal) with constitutive RET activation, where it was possible to detect a significant increase of peptidespecific CD8+ T cells after 6 months of immunization. Furthermore, it was possible to detect intratumoral infiltration of those CD8+ T cells and tumor outgrowth was reduced by approximately 57\% (Wuttke et al. 2008).

Lysate pulsed monocyte-derived mature DCs vaccination for 8 weeks in combination with low dose IL-2 was also used in phase I clinical study $(n=6)$ including PTC and FTC patients. No AEs were observed, in two patients stable disease was achieved compared with four patients suffering from progressive disease (Kuwabara et al. 2007). Unfortunately, in the recent years no further clinical trials were published using these approaches.

\section{Gastrointestinal neuroendocrine tumors and pheochromocytoma}

Gastrointestinal neuroendocrine tumors (GEP-NETs) are heterogeneous tumors originating from cells of the endocrine (hormonal) and nervous systems. The prevalence is estimated to reach 35 cases $/ 100,000$ per year (Oberg et al. 2012, Alonso-Gordoa et al. 2015). GEPNETs share morphological characteristics and may lead to hormone excess. Available medical therapies include somatostatin analogues, interferon-alpha, TKIs, mTOR inhibitor and chemotherapy (Kotteas et al. 2016).

Very recently, Kim et al. investigated the expression of PD-L1 in 32 GEP-NETs (stomach $(n=1)$, duodenum $(n=2)$, biliary tract $(n=7)$, pancreas $(n=14)$ and 8 hindgutderived GEP-NETs of distal colon and rectum using IHC. In 7 (21.9\%) patients PD-L1 expression was found and this was associated with PFS (PD-L1 positive: 4.2 months and PD-L1 negative: 5.1 months) as well as survival (PDL1 positive: 16 months and PD-L1 negative: 24.8 months), 
indicating a negative outcome for PD-L1 positive GEPNETs patients (Kim et al. 2016).

Cell-based immunotherapy has been addressed in preclinical studies of pheochromocytoma as another example of a neuroendocrine tumor. One peptide of interest was chromogranin A $(\mathrm{CgA})$. Mice with induced pheochromocytoma were vaccinated with $\mathrm{CgA}$. This resulted in larger amounts of infiltrating CD8+ cells and reduction of liver metastases (Papewalis et al. 2011). The first studies to test immune checkpoint inhibitors in neuroendocrine tumours are in the process of being started.

\section{Further immune checkpoint receptors}

Besides already approved immune checkpoint inhibitors, further molecules are currently under investigation such as T-cell immunoglobulin and mucin domain containing-3 (TIM-3) or lymphocyte activation gene 3 (LAG3). TIM-3 is highly expressed on Tregs, monocytes, macrophages and DCs and is thought to confer reduced antitumor immunity (Zhou et al. 2011). Inhibition of TIM-3 in naive CD4+ resulted in proliferation of CD8+ effector cells with increased CD8 T-cell cytotoxicity and increased TH1-mediated interferon- $\gamma$ release (Sabatos et al. 2003, Zhu et al. 2005, Boenisch et al. 2010). LAG3 is expressed on CD4, CD8 and activated Tregs (Huang et al. 2004), B cells (Kisielow et al. 2005) and a subset of NK cells (Baixeras et al. 1992). LAG3-/- mice have no T-cell defect, but show delay in cell cycle arrest (Workman et al. 2004). Interestingly, blockade of LAG3 alone does not reverse the exhausted phenotype of $\mathrm{T}$ cells in rodent tumor models, however, combined anti-LAG3/anti-PD-1 antibody therapy has been shown to induce tumor regression (Matsuzaki et al. 2010, Woo et al. 2012). Further studies on LAG3 and TIM-3 and other potentially interesting immune checkpoint proteins are summarized in an excellent review by Le Mercier et al. (2015).

\section{Future perspectives}

Endocrine cancers pose several challenges to classical oncologic regimen. One problem is that the proliferation rate and the mutational load are usually very low. Furthermore, due to their rarity and the low number of patients with an aggressive tumor biology, immunotherapy of endocrine malignancy is still at its infancy and clinical trials are mostly lacking. However, not only because of their higher mutational load, fatal endocrine cancers such as ATC, PDTC, aggressive metastatic MTC and ACC but also G3 neuroendocrine cancers could be suitable tumor entities for immunooncological treatment. It is, therefore, hoped that joint activity of scientists, endocrine cancer networks and patient groups will work toward exploring checkpoint inhibitors, including novel targets such as LAG3 and TIM-3 in combination with other oncological treatments to improve prognosis of patients with aggressive endocrine and neuroendocrine malignancies.

Declaration of interest

Bastian Schilling is on the advisory board or has received honoraria from Novartis, Roche, Bristol-Myers Squibb and MSD Sharp \& Dohme; research funding from Bristol-Myers Squibb and MSD Sharp \& Dohme and travel support from Novartis, Roche, Bristol-Myers Squibb and AMGEN. All other authors have nothing to disclose.

\section{Funding}

This review did not receive any specific grant from any funding agency in the public, commercial or not-for-profit sector.

\section{References}

Alonso-Gordoa T, Capdevila J \& Grande E 2015 GEP-NETs update: biotherapy for neuroendocrine tumours. European Journal of Endocrinology 172 R31-R46. (doi:10.1530/eje-14-0354)

Angell TE, Lechner MG, Jang JK, Correa AJ, LoPresti JS \& Epstein AL 2014 BRAF V600E in papillary thyroid carcinoma is associated with increased programmed death ligand 1 expression and suppressive immune cell infiltration. Thyroid 24 1385-1393. (doi:10.1089/thy.2014.0134)

Ansell SM, Lesokhin AM, Borrello I, Halwani A, Scott EC, Gutierrez M, Schuster SJ, Millenson MM, Cattry D, Freeman GJ, et al. 2015 PD-1 blockade with nivolumab in relapsed or refractory Hodgkin's lymphoma. New England Journal of Medicine 372 311-319. (doi:10.1056/NEJMoa1411087)

Antonia S, Goldberg SB, Balmanoukian A, Chaft JE, Sanborn RE, Gupta A, Narwal R, Steele K, Gu Y, Karakunnel JJ, et al. $2016 a$ Safety and antitumour activity of durvalumab plus tremelimumab in non-small cell lung cancer: a multicentre, phase $1 \mathrm{~b}$ study. Lancet Oncology 17 299-308. (doi:10.1016/s1470-2045(15)00544-6)

Antonia SJ, Lopez-Martin JA, Bendell J, Ott PA, Taylor M, Eder JP, Jager D, Pietanza MC, Le DT, de Braud F, et al. 2016 b Nivolumab alone and nivolumab plus ipilimumab in recurrent small-cell lung cancer (CheckMate 032): a multicentre, open-label, phase $1 / 2$ trial. Lancet Oncology 17 883-895. (doi:10.1016/s1470-2045(16)30098-5)

Attia P, Maker AV, Haworth LR, Rogers-Freezer L \& Rosenberg SA 2005 Inability of a fusion protein of IL-2 and diphtheria toxin (Denileukin Diftitox, DAB389IL-2, ONTAK) to eliminate regulatory T lymphocytes in patients with melanoma. Journal of Immunotherapy 28 582-592. (doi:10.1097/01.cji.0000175468.19742.10)

Bachleitner-Hofmann T, Friedl J, Hassler M, Hayden H, Dubsky P, Sachet M, Rieder E, Pfragner R, Brostjan C, Riss S, et al. 2009 Pilot trial of autologous dendritic cells loaded with tumor lysate(s) from allogeneic tumor cell lines in patients with metastatic medullary thyroid carcinoma. Oncology Reports 21 1585-1592. (doi:10.3892/ or_00000391) 
Baixeras E, Huard B, Miossec C, Jitsukawa S, Martin M, Hercend T, Auffray C, Triebel F \& Piatier-Tonneau D 1992 Characterization of the lymphocyte activation gene 3-encoded protein. A new ligand for human leukocyte antigen class II antigens. Journal of Experimental Medicine 176 327-337. (doi:10.1084/jem.176.2.327)

Baptista MZ, Sarian LO, Derchain SF, Pinto GA \& Vassallo J 2016 Prognostic significance of PD-L1 and PD-L2 in breast cancer. Human Pathology 47 78-84. (doi:10.1016/j.humpath.2015.09.006)

Besser MJ, Shapira-Frommer R, Treves AJ, Zippel D, Itzhaki O, Hershkovitz L, Levy D, Kubi A, Hovav E, Chermoshniuk N, et al. 2010 Clinical responses in a phase II study using adoptive transfer of short-term cultured tumor infiltration lymphocytes in metastatic melanoma patients. Clinical Cancer Research 16 2646-2655. (doi:10.1158/1078-0432.CCR-10-0041)

Bigelow E, Bever KM, Xu H, Yager A, Wu A, Taube J, Chen L, Jaffee EM, Anders RA \& Zheng L 2013 Immunohistochemical staining of B7-H1 (PD-L1) on paraffin-embedded slides of pancreatic adenocarcinoma tissue. Journal of Visualized Experiments 71 4059. (doi:10.3791/4059)

Blank CU, Haanen JB, Ribas A \& Schumacher TN 2016 Cancer immunology. The "cancer immunogram". Science 352 658-660. (doi:10.1126/science.aaf2834)

Blansfield JA, Beck KE, Tran K, Yang JC, Hughes MS, Kammula US, Royal RE, Topalian SL, Haworth LR, Levy C, et al. 2005 Cytotoxic T-lymphocyte-associated antigen- 4 blockage can induce autoimmune hypophysitis in patients with metastatic melanoma and renal cancer. Journal of Immunotherapy 28 593-598. (doi:10.1097/01. cji.0000178913.41256.06)

Boenisch O, D'Addio F, Watanabe T, Elyaman W, Magee CN, Yeung MY, Padera RF, Rodig SJ, Murayama T, Tanaka K, et al. 2010 TIM-3: a novel regulatory molecule of alloimmune activation. Journal of Immunology 185 5806-5819. (doi:10.4049/jimmunol.0903435)

Borghaei H, Paz-Ares L, Horn L, Spigel DR, Steins M, Ready NE, Chow LQ, Vokes EE, Felip E, Holgado E, et al. 2015 Nivolumab versus Docetaxel in Advanced Nonsquamous Non-Small-Cell Lung Cancer. New England Journal of Medicine 373 1627-1639. (doi:10.1056/NEJMoa1507643)

Brauner E, Gunda V, Borre PV, Zurakowski D, Kim YS, Dennett KV, Amin S, Freeman GJ \& Parangi S 2016 Combining BRAF inhibitor and anti PD-L1 antibody dramatically improves tumor regression and anti tumor immunity in an immunocompetent murine model of anaplastic thyroid cancer. Oncotarget 7 17194-17211. (doi:10.18632/oncotarget.7839)

Brose MS, Nutting CM, Jarzab B, Elisei R, Siena S, Bastholt L, de la Fouchardiere C, Pacini F, Paschke R, Shong YK, et al. 2014 Sorafenib in radioactive iodine-refractory, locally advanced or metastatic differentiated thyroid cancer: a randomised, double-blind, phase 3 trial. Lancet 384 319-328. (doi:10.1016/ s0140-6736(14)60421-9)

Champiat S, Ferte C, Lebel-Binay S, Eggermont A \& Soria JC 2014 Exomics and immunogenics: bridging mutational load and immune checkpoints efficacy. Oncoimmunology 3 e27817. (doi:10.4161/ onci.27817)

Corsello SM, Barnabei A, Marchetti P, De Vecchis L, Salvatori R \& Torino F 2013 Endocrine side effects induced by immune checkpoint inhibitors. Journal of Clinical Endocrinology and Metabolism 98 1361-1375. (doi:10.1210/jc.2012-4075)

Corthay A 2014 Does the immune system naturally protect against cancer? Frontiers in Immunology 5 197. (doi:10.3389/ fimmu.2014.00197)

Coulie PG, Van den Eynde BJ, van der Bruggen P \& Boon T 2014 Tumour antigens recognized by $\mathrm{T}$ lymphocytes: at the core of cancer immunotherapy. Nature Reviews Cancer 14 135-146. (doi:10.1038/ nrc3670)

Cunha LL, Marcello MA, Morari EC, Nonogaki S, Conte FF, Gerhard R, Soares FA, Vassallo J \& Ward LS 2013 Differentiated thyroid carcinomas may elude the immune system by B7H1 upregulation. Endocrine-Related Cancer 20 103-110. (doi:10.1530/ERC-12-0313)

Cunha LL, Morari EC, Guihen AC, Razolli D, Gerhard R, Nonogaki S, Soares FA, Vassallo J \& Ward LS 2012 Infiltration of a mixture of different immune cells may be related to molecular profile of differentiated thyroid cancer. Endocrine-Related Cancer 19 L31-L36. (doi:10.1530/erc-11-0285)

Curti BD, Longo DL, Ochoa AC, Conlon KC, Smith JW, 2nd, Alvord WG, Creekmore SP, Fenton RG, Gause BL, Holmlund J, et al. 1993 Treatment of cancer patients with ex vivo anti-CD3activated killer cells and interleukin-2. Journal of Clinical Oncology 11 652-660.

Dillard T, Yedinak CG, Alumkal J \& Fleseriu M 2010 Anti-CTLA-4 antibody therapy associated autoimmune hypophysitis: serious immune related adverse events across a spectrum of cancer subtypes. Pituitary 13 29-38. (doi:10.1007/s11102-009-0193-z)

Dong H, Strome SE, Salomao DR, Tamura H, Hirano F, Flies DB, Roche PC, Lu J, Zhu G, Tamada K, et al. 2002 Tumor-associated B7-H1 promotes T-cell apoptosis: a potential mechanism of immune evasion. Nature Medicine 8 793-800. (doi:10.1038/nm730)

Dreno B, Nguyen JM, Khammari A, Pandolfino MC, Tessier MH, Bercegeay S, Cassidanius A, Lemarre P, Billaudel S, Labarriere N, et al. 2002 Randomized trial of adoptive transfer of melanoma tumorinfiltrating lymphocytes as adjuvant therapy for stage III melanoma. Cancer Immunology, Immunotherapy 51 539-546. (doi:10.1007/s00262002-0315-1)

Dudley ME, Wunderlich JR, Yang JC, Sherry RM, Topalian SL, Restifo NP, Royal RE, Kammula U, White DE, Mavroukakis SA, et al. 2005 Adoptive cell transfer therapy following non-myeloablative but lymphodepleting chemotherapy for the treatment of patients with refractory metastatic melanoma. Journal of Clinical Oncology 23 2346-2357. (doi:10.1200/JCO.2005.00.240)

Eggermont AM, Chiarion-Sileni V, Grob JJ, Dummer R, Wolchok JD, Schmidt H, Hamid O, Robert C, Ascierto PA, Richards JM, et al. 2015 Adjuvant ipilimumab versus placebo after complete resection of high-risk stage III melanoma (EORTC 18071): a randomised, doubleblind, phase 3 trial. Lancet Oncology 16 522-530. (doi:10.1016/S14702045(15)70122-1)

Eisenhauer EA, Therasse P, Bogaerts J, Schwartz LH, Sargent D, Ford R, Dancey J, Arbuck S, Gwyther S, Mooney M, et al. 2009 New response evaluation criteria in solid tumours: revised RECIST guideline (version 1.1). European Journal of Cancer 45 228-247. (doi:10.1016/j. ejca.2008.10.026)

Elisei R, Schlumberger MJ, Muller SP, Schoffski P, Brose MS, Shah MH, Licitra L, Jarzab B, Medvedev V, Kreissl MC, et al. 2013 Cabozantinib in progressive medullary thyroid cancer. Journal of Clinical Oncology 31 3639-3646. (doi:10.1200/JCO.2012.48.4659)

Fusi A, Festino L, Botti G, Masucci G, Melero I, Lorigan P \& Ascierto PA 2015 PD-L1 expression as a potential predictive biomarker. Lancet Oncology 16 1285-1287. (doi:10.1016/S1470-2045(15)00307-1)

Garon EB, Rizvi NA, Hui R, Leighl N, Balmanoukian AS, Eder JP, Patnaik A, Aggarwal C, Gubens M, Horn L, et al. 2015 Pembrolizumab for the treatment of non-small-cell lung cancer. New England Journal of Medicine 372 2018-2028. (doi:10.1056/ NEJMoa1501824)

Gjertsen MK, Bakka A, Breivik J, Saeterdal I, Gedde-Dahl T, 3rd, Stokke KT, Solheim BG, Egge TS, Soreide O, Thorsby E, et al. 1996 Ex vivo ras peptide vaccination in patients with advanced pancreatic cancer: results of a phase I/II study. International Journal of Cancer $\mathbf{6 5}$ 450-453. (doi:10.1002/(sici)1097-0215(19960208)65:4<450::aidijc10>3.0.co;2-e)

Greco A, Albanese S, Auletta L, Mirabelli P, Zannetti A, D’Alterio C, Di Maro G, Orlandella FM, Salvatore G, Soricelli A, et al. 2016 Highfrequency ultrasound-guided injection for the generation of a novel orthotopic mouse model of human thyroid carcinoma. Thyroid $\mathbf{2 6}$ 552-558. (doi:10.1089/thy.2015.0511) 
Hanahan D \& Weinberg RA 2000 The hallmarks of cancer. Cell 100 57-70. (doi:10.1016/S0092-8674(00)81683-9)

Hanahan D \& Weinberg RA 2011 Hallmarks of cancer: the next generation. Cell 144 646-674. (doi:10.1016/j.cell.2011.02.013)

Harris JA, Jain S, Ren Q, Zarineh A, Liu C \& Ibrahim S 2012 CD163 versus CD68 in tumor associated macrophages of classical Hodgkin lymphoma. Diagnostic Pathology 7 12. (doi:10.1186/17461596-7-12)

Herbst RS, Soria JC, Kowanetz M, Fine GD, Hamid O, Gordon MS, Sosman JA, McDermott DF, Powderly JD, Gettinger SN, et al. 2014 Predictive correlates of response to the anti-PD-L1 antibody MPDL3280A in cancer patients. Nature 515 563-567. (doi:10.1038/ nature14011)

Herbst RS, Baas P, Kim DW, Felip E, Perez-Gracia JL, Han JY, Molina J, Kim JH, Arvis CD, Ahn MJ, et al. 2016 Pembrolizumab versus docetaxel for previously treated, PD-L1-positive, advanced non-small-cell lung cancer (KEYNOTE-010): a randomised controlled trial. Lancet 387 1540-1550. (doi:10.1016/S01406736(15)01281-7)

Hodi FS, O'Day SJ, McDermott DF, Weber RW, Sosman JA, Haanen JB, Gonzalez R, Robert C, Schadendorf D, Hassel JC, et al. 2010 Improved survival with ipilimumab in patients with metastatic melanoma. N England Journal of Medicine 363 711-723. (doi:10.1056/ NEJMoa1003466)

Hodi FS, Lawrence D, Lezcano C, Wu X, Zhou J, Sasada T, Zeng W, Giobbie-Hurder A, Atkins MB, Ibrahim N, et al. 2014 Bevacizumab plus ipilimumab in patients with metastatic melanoma. Cancer Immunology Research 2 632-642. (doi:10.1158/2326-6066.CIR-140053)

Hodi FS, Hwu W-J, Kefford R, Weber JS, Daud A, Hamid O, Patnaik A, Ribas A, Robert C, Gangadhar TC, et al. 2016 Evaluation of Immune-Related Response Criteria and RECIST v1.1 in Patients With Advanced Melanoma Treated With Pembrolizumab. Journal of Clinical Oncology 34 1510-1517. (doi:10.1200/JCO.2015.64.0391)

Hofmann L, Forschner A, Loquai C, Goldinger SM, Zimmer L, Ugurel S, Schmidgen MI, Gutzmer R, Utikal JS, Goppner D, et al. 2016 Cutaneous, gastrointestinal, hepatic, endocrine, and renal sideeffects of anti-PD-1 therapy. European Journal of Cancer 60 190-209. (doi:10.1016/j.ejca.2016.02.025)

Hoos A, Wolchok JD, Humphrey RW \& Hodi FS 2015 CCR 20th anniversary commentary: immune-related response criteria capturing clinical activity in immuno-oncology. Clinical Cancer Research 21 4989-4991. (doi:10.1158/1078-0432.CCR-14-3128)

Huang CT, Workman CJ, Flies D, Pan X, Marson AL, Zhou G, Hipkiss EL, Ravi S, Kowalski J, Levitsky HI, et al. 2004 Role of LAG-3 in regulatory T cells. Immunity 21 503-513. (doi:10.1016/j. immuni.2004.08.010)

Huang FJ, Zhou XY, Ye L, Fei XC, Wang S, Wang W \& Ning G 2015 Follicular thyroid carcinoma but not adenoma recruits tumorassociated macrophages by releasing CCL15. BMC Cancer 1698 (doi:10.1186/s12885-016-2114-7)

Imam S, Paparodis R, Sharma D \& Jaume JC 2014 Lymphocytic profiling in thyroid cancer provides clues for failure of tumor immunity. Endocrine-Related Cancer 21 505-516. (doi:10.1530/ERC-13-0436)

Ishida Y, Agata Y, Shibahara K \& Honjo T 1992 Induced expression of PD-1, a novel member of the immunoglobulin gene superfamily, upon programmed cell death. EMBO Journal 11 3887-3895.

Iwai Y, Ishida M, Tanaka Y, Okazaki T, Honjo T \& Minato N 2002 Involvement of PD-L1 on tumor cells in the escape from host immune system and tumor immunotherapy by PD-L1 blockade. PNAS 99 12293-12297. (doi:10.1073/pnas.192461099)

Jeanbart L \& Swartz MA 2015 Engineering opportunities in cancer immunotherapy. PNAS 112 14467-14472. (doi:10.1073/ pnas.1508516112)

Joseph Grosso DI, Qiuyan Wu, Jason Simon, Parul Singh, Xiaoling Zhang, Therese Phillips, Pauline Simmons, John Cogswell 2013
Programmed death-ligand 1 (PD-L1) expression in various tumor types. Society for Immunotherapy of Cancer 28th Annual Meeting Poster presentation.

Jung KY, Cho SW, Kim YA, Kim D, Oh BC, Park do J \& Park YJ 2015 Cancers with higher density of tumor-associated macrophages were associated with poor survival rates. Journal of Pathology and Translational Medicine 49 318-324. (doi:10.4132/jptm.2015.06.01)

Kim ST, Ha SY, Lee S, Ahn S, Lee J, Park SH, Park JO, Lim HY, Kang WK, Kim KM, et al. 2016 The impact of PD-L1 expression in patients with metastatic GEP-NETs. Journal of Cancer 7 484-489. (doi:10.7150/ jca.13711)

Kisielow M, Kisielow J, Capoferri-Sollami G \& Karjalainen K 2005 Expression of lymphocyte activation gene 3 (LAG-3) on B cells is induced by T cells. European Journal of Immunology 35 2081-2088. (doi:10.1002/eji.200526090)

Klement GL 2016 Eco-evolution of cancer resistance. Science Translational Medicine 8 327fs325. (doi:10.1126/scitranslmed.aaf3802)

Knauf JA, Ma X, Smith EP, Zhang L, Mitsutake N, Liao XH, Refetoff S, Nikiforov YE \& Fagin JA 2005 Targeted expression of BRAFV600E in thyroid cells of transgenic mice results in papillary thyroid cancers that undergo dedifferentiation. Cancer Research 65 4238-4245. (doi:10.1158/0008-5472.CAN-05-0047)

Kotteas E, Saif MW \& Syrigos K 2016 Immunotherapy for pancreatic cancer. Journal of Cancer Research and Clinical Oncology 142 1795-1805. (doi:10.1007/s00432-016-2119-2)

Kradin RL, Kurnick JT, Lazarus DS, Preffer FI, Dubinett SM, Pinto CE, Gifford J, Davidson E, Grove B, Callahan RJ, et al. 1989 Tumourinfiltrating lymphocytes and interleukin-2 in treatment of advanced cancer. Lancet 1 577-580. (doi:10.1016/s0140-6736(89)91609-7)

Krummel MF \& Allison JP 1995 CD28 and CTLA-4 have opposing effects on the response of $\mathrm{T}$ cells to stimulation. Journal of Experimental Medicine 182 459-465. (doi:10.1084/jem.182.2.459)

Kulke MH, Lenz HJ, Meropol NJ, Posey J, Ryan DP, Picus J, Bergsland E, Stuart K, Tye L, Huang X, et al. 2008 Activity of sunitinib in patients with advanced neuroendocrine tumors. Journal of Clinical Oncology 26 3403-3410. (doi:10.1200/JCO.2007.15.9020)

Kuwabara K, Nishishita T, Morishita M, Oyaizu N, Yamashita S, Kanematsu T, Obara T, Mimura Y, Inoue Y, Kaminishi M, et al. 2007 Results of a phase I clinical study using dendritic cell vaccinations for thyroid cancer. Thyroid 17 53-58. (doi:10.1089/ thy.2006.0178)

Kwon ED, Hurwitz AA, Foster BA, Madias C, Feldhaus AL, Greenberg NM, Burg MB \& Allison JP 1997 Manipulation of T cell costimulatory and inhibitory signals for immunotherapy of prostate cancer. PNAS 94 8099-8103. (doi:10.1073/pnas.94.15.8099)

Lan KH, Liu YC, Shih YS, Tsaid CL, Yen SH \& Lan KL 2013 A DNA vaccine against cytotoxic T-lymphocyte associated antigen-4 (CTLA-4) prevents tumor growth. Biochemical and Biophysical Research Communications 440 222-228. (doi:10.1016/j.bbrc.2013.09.031)

Landa I, Ibrahimpasic T, Boucai L, Sinha R, Knauf JA, Shah RH, Dogan S, Ricarte-Filho JC, Krishnamoorthy GP, Xu B, et al. 2016 Genomic and transcriptomic hallmarks of poorly differentiated and anaplastic thyroid cancers. Journal of Clinical Investigation 126 1052-1066. (doi:10.1172/JCI85271)

Larkin J, Ascierto PA, Dreno B, Atkinson V, Liszkay G, Maio M, Mandala M, Demidov L, Stroyakovskiy D, Thomas L, et al. 2014 Combined vemurafenib and cobimetinib in BRAF-mutated melanoma. New England Journal of Medicine 371 1867-1876. (doi:10.1056/NEJMoa1408868)

Larkin J, Chiarion-Sileni V, Gonzalez R, Grob JJ, Cowey CL, Lao CD, Schadendorf D, Dummer R, Smylie M, Rutkowski P, et al. 2015 Combined Nivolumab and Ipilimumab or Monotherapy in Untreated Melanoma. New England Journal of Medicine 373 23-34. (doi:10.1056/NEJMoa1504030)

Latchman Y, Wood CR, Chernova T, Chaudhary D, Borde M, Chernova I, Iwai Y, Long AJ, Brown JA, Nunes R, et al. 2001 PD-L2 is

Published by Bioscientifica Ltd. 
a second ligand for PD-1 and inhibits T cell activation. Nature Immunology 2 261-268. (doi:10.1038/85330)

Le Mercier I, Lines JL \& Noelle RJ 2015 Beyond CTLA-4 and PD-1, the generation $\mathrm{Z}$ of negative checkpoint regulators. Frontiers in Immunology 6 418. (doi:10.3389/fimmu.2015.00418)

Leach DR, Krummel MF \& Allison JP 1996 Enhancement of antitumor immunity by CTLA-4 blockade. Science 271 1734-1736. (doi:10.1126/science.271.5256.1734)

Leng C, Li Y, Qin J, Ma J, Liu X, Cui Y, Sun H, Wang Z, Hua X, Yu Y, et al. 2016 Relationship between expression of PD-L1 and PD-L2 on esophageal squamous cell carcinoma and the antitumor effects of CD8+ T cells. Oncology Reports 35 699-708. (doi:10.3892/or.2015.4435)

Levitzki A 2013 Tyrosine kinase inhibitors: views of selectivity, sensitivity, and clinical performance. Annual Review of Pharmacology and Toxicology 53 161-185. (doi:10.1146/annurev-pharmtox-011112-140341)

Li F, Guo Z, Yu H, Zhang X, Si T, Liu C, Yang X \& Qi L 2014 Anti-tumor immunological response induced by cryoablation and anti-CTLA-4 antibody in an in vivo RM-1 cell prostate cancer murine model. Neoplasma 61 659-671. (doi:10.4149/neo_2014_081)

Long GV, Stroyakovskiy D, Gogas H, Levchenko E, de Braud F, Larkin J, Garbe C, Jouary T, Hauschild A, Grob JJ, et al. 2014 Combined BRAF and MEK inhibition versus BRAF inhibition alone in melanoma. New England Journal of Medicine 371 1877-1888. (doi:10.1056/ NEJMoa1406037)

Mahnke K, Schonfeld K, Fondel S, Ring S, Karakhanova S, Wiedemeyer K, Bedke T, Johnson TS, Storn V, Schallenberg S, et al. 2007 Depletion of CD4+CD25+ human regulatory T cells in vivo: kinetics of Treg depletion and alterations in immune functions in vivo and in vitro. International Journal of Cancer 120 2723-2733. (doi:10.1002/ijc.22617)

Malm IJ, Bruno TC, Fu J, Zeng Q, Taube JM, Westra W, Pardoll D, Drake CG \& Kim YJ 2015 Expression profile and in vitro blockade of programmed death-1 in human papillomavirus-negative head and neck squamous cell carcinoma. Head and Neck 37 1088-1095. (doi:10.1002/hed.23706)

Manson G, Norwood J, Marabelle A, Kohrt H \& Houot R 2016 Biomarkers associated with checkpoint inhibitors. Annals of Oncology 27 1199-1206. (doi:10.1093/annonc/mdw181)

Martens A, Wistuba-Hamprecht K, Foppen MG, Yuan J, Postow MA, Wong P, Romano E, Khammari A, Dreno B, Capone M, et al. 2016 Baseline peripheral blood biomarkers associated with clinical outcome of advanced melanoma patients treated with ipilimumab. Clinical Cancer Research 22 2908-2918. (doi:10.1158/1078-0432.CCR15-2412)

Matsuzaki J, Gnjatic S, Mhawech-Fauceglia P, Beck A, Miller A, Tsuji T, Eppolito C, Qian F, Lele S, Shrikant P, et al. 2010 Tumor-infiltrating NY-ESO-1-specific CD8+ T cells are negatively regulated by LAG-3 and PD-1 in human ovarian cancer. PNAS 107 7875-7880. (doi:10.1073/pnas.1003345107)

McDaniela AS, Alva A, Zhand T, Xiaoa H, Caoa X, Gurskyg A, Siddiquia J, Chinnaiyana AM, Jiangd H, Leec CT, et al. 2015 Expression of PDL1 (B7-H1) Before and After Neoadjuvant Chemotherapy in Urothelial Carcinoma. European Urology Focus $\mathbf{1}$ 265-268. (doi:10.1016/j.euf.2015.03.004)

McGranahan N, Furness AJ, Rosenthal R, Ramskov S, Lyngaa R, Saini SK, Jamal-Hanjani M, Wilson GA, Birkbak NJ, Hiley CT, et al. 2016 Clonal neoantigens elicit $\mathrm{T}$ cell immunoreactivity and sensitivity to immune checkpoint blockade. Science 351 1463-1469. (doi:10.1126/ science.aaf1490)

Melero I, Berman DM, Aznar MA, Korman AJ, Perez Gracia JL \& Haanen J 2015 Evolving synergistic combinations of targeted immunotherapies to combat cancer. Nature Reviews Cancer 15 457-472. (doi:10.1038/nrc3973)

Min L, Vaidya A \& Becker C 2011 Thyroid autoimmunity and ophthalmopathy related to melanoma biological therapy. European Journal of Endocrinology 164 303-307. (doi:10.1530/EJE-10-0833)
Moller P, Moller H, Sun Y, Dorbic T, Henz BM, Wittig B \& Schadendorf D 2000 Increased non-major histocompatibility complex-restricted lytic activity in melanoma patients vaccinated with cytokine gene-transfected autologous tumor cells. Cancer Gene Therapy 7 976-984. (doi:10.1038/sj.cgt.7700203)

Motzer RJ, Escudier B, McDermott DF, George S, Hammers HJ, Srinivas S, Tykodi SS, Sosman JA, Procopio G, Plimack ER, et al. 2015 Nivolumab versus everolimus in advanced renal-cell carcinoma. New England Journal of Medicine 373 1803-1813. (doi:10.1056/ NEJMoa1510665)

Nguyen TT, Schwartz EJ, West RB, Warnke RA, Arber DA \& Natkunam Y 2005 Expression of CD163 (hemoglobin scavenger receptor) in normal tissues, lymphomas, carcinomas, and sarcomas is largely restricted to the monocyte/macrophage lineage. American Journal of Surgical Pathology 29 617-624. (doi:10.1097/01. pas.0000157940.80538.ec)

Oberg K, Knigge U, Kwekkeboom D, Perren A \& Group EGW 2012 Neuroendocrine gastro-entero-pancreatic tumors: ESMO Clinical Practice Guidelines for diagnosis, treatment and follow-up. Annals of Oncology 23 vii124-130. (doi:10.1093/annonc/mds295)

Okada H, Weller M, Huang R, Finocchiaro G, Gilbert MR, Wick W, Ellingson BM, Hashimoto N, Pollack IF, Brandes AA, et al. 2015 Immunotherapy response assessment in neuro-oncology: a report of the RANO working group. Lancet Oncology 16 e534-e542. (doi:10.1016/S1470-2045(15)00088-1)

Papewalis C, Wuttke M, Jacobs B, Domberg J, Willenberg H, Baehring T, Cupisti K, Raffel A, Chao L, Fenk R, et al. 2008 Dendritic cell vaccination induces tumor epitope-specific Th1 immune response in medullary thyroid carcinoma. Hormone and Metabolic Research 40 108-116. (doi:10.1055/s-2007-1022565)

Papewalis C, Kouatchoua C, Ehlers M, Jacobs B, Porwol D, Schinner S, Willenberg HS, Anlauf M, Raffel A, Eisenhofer G, et al. 2011 Chromogranin A as potential target for immunotherapy of malignant pheochromocytoma. Molecular and Cellular Endocrinology 335 69-77. (doi:10.1016/j.mce.2010.05.021)

Parhar RS, Zou M, Al-Mohanna FA, Baitei EY, Assiri AM, Meyer BF \& Shi Y 2016 IL-12 immunotherapy of Braf(V600E)-induced papillary thyroid cancer in a mouse model. Laboratory Investigation 96 89-97. (doi:10.1038/labinvest.2015.126)

Pizza G, Viza D, De Vinci C, Vich i Pascuchi JM, Busutti L \& Bergami T 1988 Intra-lymphatic administration of interleukin-2 (IL-2) in cancer patients: a pilot study. Lymphokine Research 7 45-48.

Raymond E, Dahan L, Raoul JL, Bang YJ, Borbath I, Lombard-Bohas C, Valle J, Metrakos P, Smith D, Vinik A, et al. 2011 Sunitinib malate for the treatment of pancreatic neuroendocrine tumors. New England Journal of Medicine 364 501-513. (doi:10.1056/nejmoa1003825)

Ribas A, Kefford R, Marshall MA, Punt CJ, Haanen JB, Marmol M, Garbe C, Gogas H, Schachter J, Linette G, et al. 2013 Phase III randomized clinical trial comparing tremelimumab with standard-ofcare chemotherapy in patients with advanced melanoma. Journal of Clinical Oncology 31 616-622. (doi:10.1200/JCO.2012.44.6112)

Rizvi NA, Hellmann MD, Snyder A, Kvistborg P, Makarov V, Havel JJ, Lee W, Yuan J, Wong P, Ho TS, et al. 2015 Cancer immunology. Mutational landscape determines sensitivity to PD-1 blockade in non-small cell lung cancer. Science 348 124-128. (doi:10.1126/ science.aaa1348)

Robert C, Thomas L, Bondarenko I, O’Day S, Weber J, Garbe C, Lebbe C, Baurain JF, Testori A, Grob JJ, et al. 2011 Ipilimumab plus dacarbazine for previously untreated metastatic melanoma. New England Journal of Medicine 364 2517-2526. (doi:10.1056/ NEJMoa1104621)

Robert C, Long GV, Brady B, Dutriaux C, Maio M, Mortier L, Hassel JC, Rutkowski P, McNeil C, Kalinka-Warzocha E, et al. 2015a Nivolumab in previously untreated melanoma without BRAF mutation. New England Journal of Medicine 372 320-330. (doi:10.1056/ NEJMoa1412082) 
Robert C, Schachter J, Long GV, Arance A, Grob JJ, Mortier L, Daud A, Carlino MS, McNeil C, Lotem M, et al. 2015b Pembrolizumab versus Ipilimumab in advanced melanoma. New England Journal of Medicine 372 2521-2532. (doi:10.1056/NEJMoa1503093)

Rock KL, Fleischacker C \& Gamble S 1993 Peptide-priming of cytolytic T cell immunity in vivo using beta 2-microglobulin as an adjuvant. Journal of Immunology 150 1244-1252.

Rosenberg SA, Lotze MT, Yang JC, Aebersold PM, Linehan WM, Seipp CA \& White DE 1989 Experience with the use of high-dose interleukin-2 in the treatment of 652 cancer patients. Annals of Surgery 210 474-484. (doi:10.1097/00000658-198910000-00008)

Rosenwald A, Wright G, Leroy K, Yu X, Gaulard P, Gascoyne RD, Chan WC, Zhao T, Haioun C, Greiner TC, et al. 2003 Molecular diagnosis of primary mediastinal B cell lymphoma identifies a clinically favorable subgroup of diffuse large B cell lymphoma related to Hodgkin lymphoma. Journal of Experimental Medicine 198 851-862. (doi:10.1084/jem.20031074)

Royal RE, Levy C, Turner K, Mathur A, Hughes M, Kammula US Sherry RM, Topalian SL, Yang JC, Lowy I, et al. 2010 Phase 2 trial of single agent Ipilimumab (anti-CTLA-4) for locally advanced or metastatic pancreatic adenocarcinoma. Journal of Immunotherapy $\mathbf{3 3}$ 828-833. (doi:10.1097/CJI.0b013e3181eec14c)

Ryder M, Callahan M, Postow MA, Wolchok J \& Fagin JA 2014 Endocrine-related adverse events following ipilimumab in patients with advanced melanoma: a comprehensive retrospective review from a single institution. Endocrine-Related Cancer 21 371-381. (doi:10.1530/ERC-13-0499)

Ryder M, Ghossein RA, Ricarte-Filho JC, Knauf JA \& Fagin JA 2008 Increased density of tumor-associated macrophages is associated with decreased survival in advanced thyroid cancer. Endocrine-Related Cancer 15 1069-1074. (doi:10.1677/ERC-08-0036)

Sabatos CA, Chakravarti S, Cha E, Schubart A, Sanchez-Fueyo A, Zheng XX, Coyle AJ, Strom TB, Freeman GJ \& Kuchroo VK 2003 Interaction of Tim-3 and Tim-3 ligand regulates T helper type 1 responses and induction of peripheral tolerance. Nature Immunology 4 1102-1110. (doi:10.1038/ni988)

Schadendorf D, Hodi FS, Robert C, Weber JS, Margolin K, Hamid O, Patt D, Chen TT, Berman DM \& Wolchok JD 2015 Pooled analysis of long-term survival data from phase II and phase III trials of ipilimumab in unresectable or metastatic melanoma. Journal of Clinical Oncology 33 1889-1894. (doi:10.1200/JCO.2014. 56.2736)

Schlumberger M, Tahara M, Wirth LJ, Robinson B, Brose MS, Elisei R, Habra MA, Newbold K, Shah MH, Hoff AO, et al. 2015 Lenvatinib versus placebo in radioiodine-refractory thyroid cancer. New England Journal of Medicine 372 621-630. (doi:10.1056/NEJMoa1406470)

Schott M, Seissler J, Lettmann M, Fouxon V, Scherbaum WA \& Feldkamp J 2001 Immunotherapy for medullary thyroid carcinoma by dendritic cell vaccination. Journal of Clinical Endocrinology and Metabolism 86 4965-4969. (doi:10.1210/jcem.86.10.7949)

Schumacher TN \& Schreiber RD 2015 Neoantigens in cancer immunotherapy. Science 348 69-74. (doi:10.1126/science.aaa4971)

Shrikant P, Khoruts A \& Mescher MF 1999 CTLA-4 blockade reverses CD8+ T cell tolerance to tumor by a CD4+ T cell- and IL-2dependent mechanism. Immunity 11 483-493. (doi:10.1016/S10747613(00)80123-5)

Socinski MA 2015 Incorporating immunotherapy into the treatment of non-small cell lung cancer: practical guidance for the clinic. Seminars in Oncology 42 S19-S28. (doi:10.1053/ j.seminoncol.2015.09.017)

Son CH, Bae JH, Shin DY, Lee HR, Choi YJ, Jo WS, Ho Jung M, Kang CD, Yang K \& Park YS 2014 CTLA-4 blockade enhances antitumor immunity of intratumoral injection of immature dendritic cells into irradiated tumor in a mouse colon cancer model. Journal of Immunotherapy 37 1-7. (doi:10.1097/CJI.0000000000000007)
Sotomayor EM, Borrello I, Tubb E, Allison JP \& Levitsky HI 1999 In vivo blockade of CTLA-4 enhances the priming of responsive T cells but fails to prevent the induction of tumor antigen-specific tolerance. PNAS 96 11476-11481. (doi:10.1073/pnas.96.20.11476)

Spranger S, Spaapen RM, Zha Y, Williams J, Meng Y, Ha TT \& Gajewski TF 2013 Up-regulation of PD-L1, IDO, and T(regs) in the melanoma tumor microenvironment is driven by CD8(+) T cells. Science Translational Medicine 5 200ra116. (doi:10.1126/ scitranslmed.3006504)

Telang S, Rasku MA, Clem AL, Carter K, Klarer AC, Badger WR, Milam RA, Rai SN, Pan J, Gragg H, et al. 2011 Phase II trial of the regulatory $\mathrm{T}$ cell-depleting agent, denileukin diftitox, in patients with unresectable stage IV melanoma. BMC Cancer 11515. (doi:10.1186/1471-2407-11-515)

Topalian SL, Drake CG \& Pardoll DM 2015 Immune checkpoint blockade: a common denominator approach to cancer therapy. Cancer Cell 27 450-461. (doi:10.1016/j.ccell.2015.03.001)

Topalian SL, Hodi FS, Brahmer JR, Gettinger SN, Smith DC, McDermott DF, Powderly JD, Carvajal RD, Sosman JA, Atkins MB, et al. 2012 Safety, activity, and immune correlates of anti-PD-1 antibody in cancer. New England Journal of Medicine 366 2443-2454. (doi:10.1056/NEJMoa1200690)

Topalian SL, Solomon D, Avis FP, Chang AE, Freerksen DL, Linehan WM, Lotze MT, Robertson CN, Seipp CA, Simon P, et al. 1988 Immunotherapy of patients with advanced cancer using tumor-infiltrating lymphocytes and recombinant interleukin-2: a pilot study. Journal of Clinical Oncology 6 839-853.

Triebel F, Jitsukawa S, Baixeras E, Roman-Roman S, Genevee C, Viegas-Pequignot E \& Hercend T 1990 LAG-3, a novel lymphocyte activation gene closely related to CD4. Journal of Experimental Medicine 171 1393-1405. (doi:10.1084/jem.171.5.1393)

Tumeh PC, Harview CL, Yearley JH, Shintaku IP, Taylor EJ, Robert L, Chmielowski B, Spasic M, Henry G, Ciobanu V, et al. 2014 PD-1 blockade induces responses by inhibiting adaptive immune resistance. Nature 515 568-571. (doi:10.1038/nature13954)

Vadhan-Raj S, Nathan CF, Sherwin SA, Oettgen HF \& Krown SE 1986 Phase I trial of recombinant interferon gamma by 1-hour i.v. infusion. Cancer Treatment Reports 70 609-614.

Van Allen EM, Miao D, Schilling B, Shukla SA, Blank C, Zimmer L, Sucker A, Hillen U, Foppen MH, Goldinger SM, et al. 2015 Genomic correlates of response to CTLA-4 blockade in metastatic melanoma. Science 350 207-211. (doi:10.1126/science.aad0095)

Vietti TJ, Sullivan MP, Berry DH, Haddy TB, Haggard ME \& Blattner RJ 1965 The Response of Acute Childhood Leukemia to an Initial and a Second Course of Prednisone. Journal of Pediatrics 66 18-26. (doi:10.1016/S0022-3476(65)80334-1)

Walunas TL, Lenschow DJ, Bakker CY, Linsley PS, Freeman GJ, Green JM, Thompson CB \& Bluestone JA 1994 CTLA-4 can function as a negative regulator of $\mathrm{T}$ cell activation. Immunity $\mathbf{1} 405-413$. (doi:10.1016/1074-7613(94)90071-X)

Walunas TL, Bakker CY \& Bluestone JA 1996 CTLA-4 ligation blocks CD28-dependent T cell activation. Journal of Experimental Medicine 183 2541-2550. (doi:10.1084/jem.183.6.2541)

Waterhouse P, Penninger JM, Timms E, Wakeham A, Shahinian A Lee KP, Thompson CB, Griesser H \& Mak TW 1995 Lymphoproliferative disorders with early lethality in mice deficient in Ctla-4. Science 270 985-988. (doi:10.1126/ science.270.5238.985)

Weber JS, D'Angelo SP, Minor D, Hodi FS, Gutzmer R, Neyns B, Hoeller C, Khushalani NI, Miller WH, Jr., Lao CD, et al. 2015 Nivolumab versus chemotherapy in patients with advanced melanoma who progressed after anti-CTLA-4 treatment (CheckMate 037): a randomised, controlled, open-label, phase 3 trial. Lancet Oncology 16 375-384. (doi:10.1016/S1470-2045(15)70076-8)

Weide B, Martens A, Hassel JC, Berking C, Postow MA, Bisschop K, Simeone E, Mangana J, Schilling B, Di Giacomo AM, et al. 2016 
Baseline biomarkers for outcome of melanoma patients treated with pembrolizumab. Clinical Cancer Research [in press]. (doi:10.1158/1078-0432.CCR-16-0127)

Wells SA, Robinson BG, Gagel RF, Dralle H, Fagin JA, Santoro M, Baudin E, Elisei R, Jarzab B, Vasselli JR, et al. 2012 Vandetanib in patients with locally advanced or metastatic medullary thyroid cancer: a randomized, double-blind phase III trial. Journal of Clinical Oncology 30 134-141. (doi:10.1200/JCO. 2011.35.5040)

Westin JR, Chu F, Zhang M, Fayad LE, Kwak LW, Fowler N, Romaguera J, Hagemeister F, Fanale M, Samaniego F, et al. 2014 Safety and activity of PD1 blockade by pidilizumab in combination with rituximab in patients with relapsed follicular lymphoma: a single group, open-label, phase 2 trial. Lancet Oncology 15 69-77. (doi:10.1016/ S1470-2045(13)70551-5)

Wolchok JD, Hoos A, O'Day S, Weber JS, Hamid O, Lebbe C, Maio M, Binder M, Bohnsack O, Nichol G, et al. 2009 Guidelines for the evaluation of immune therapy activity in solid tumors: immunerelated response criteria. Clinical Cancer Research 15 7412-7420. (doi:10.1158/1078-0432.CCR-09-1624)

Woo SR, Turnis ME, Goldberg MV, Bankoti J, Selby M, Nirschl CJ, Bettini ML, Gravano DM, Vogel P, Liu CL, et al. 2012 Immune inhibitory molecules LAG-3 and PD-1 synergistically regulate T-cell function to promote tumoral immune escape. Cancer Research 72 917-927. (doi:10.1158/0008-5472.CAN11-1620)

Workman CJ, Cauley LS, Kim IJ, Blackman MA, Woodland DL \& Vignali DA 2004 Lymphocyte activation gene-3 (CD223) regulates the size of the expanding $\mathrm{T}$ cell population following antigen activation in vivo. Journal of Immunology 172 5450-5455. (doi:10.4049/jimmunol.172.9.5450)

Wu C, Zhu Y, Jiang J, Zhao J, Zhang XG \& Xu N 2006 Immunohistochemical localization of programmed death-1 ligand-1 (PD-L1) in gastric carcinoma and its clinical significance. Acta Histochemica 108 19-24. (doi:10.1016/j.acthis.2006.01.003)
Wu R, Forget MA, Chacon J, Bernatchez C, Haymaker C, Chen JQ, Hwu P \& Radvanyi LG 2012 Adoptive T-cell therapy using autologous tumor-infiltrating lymphocytes for metastatic melanoma: current status and future outlook. Cancer Journal 18 160-175. (doi:10.1097/PPO.0b013e31824d4465)

Wuttke M, Papewalis C, Meyer Y, Kessler C, Jacobs B, Willenberg HS, Schinner S, Kouatchoua C, Baehring T, Scherbaum WA, et al. 2008 Amino acid-modified calcitonin immunization induces tumor epitope-specific immunity in a transgenic mouse model for medullary thyroid carcinoma. Endocrinology 149 5627-5634. (doi:10.1210/en.2008-0631)

Yang JC, Hughes M, Kammula U, Royal R, Sherry RM, Topalian SL, Suri KB, Levy C, Allen T, Mavroukakis S, et al. 2007 Ipilimumab (anti-CTLA4 antibody) causes regression of metastatic renal cell cancer associated with enteritis and hypophysitis. Journal of Immunotherapy 30 825-830. (doi:10.1097/CJI. 0b013e318156e47e)

Yi DH \& Appel S 2013 Current status and future perspectives of dendritic cell-based cancer immunotherapy. Scandinavian Journal of Immunology 78 167-171. (doi:10.1111/sji.12060)

Zhou Q, Munger ME, Veenstra RG, Weigel BJ, Hirashima M, Munn DH, Murphy WJ, Azuma M, Anderson AC, Kuchroo VK, et al. 2011 Coexpression of Tim-3 and PD-1 identifies a CD8+ T-cell exhaustion phenotype in mice with disseminated acute myelogenous leukemia. Blood 117 4501-4510. (doi:10.1182/blood2010-10-310425)

Zhu C, Anderson AC, Schubart A, Xiong H, Imitola J, Khoury SJ, Zheng XX, Strom TB \& Kuchroo VK 2005 The Tim-3 ligand galectin-9 negatively regulates T helper type 1 immunity. Nature Immunology 6 1245-1252. (doi:10.1038/ni1271)

Zimmer L, Goldinger SM, Hofmann L, Loquai C, Ugurel S, Thomas I, Schmidgen MI, Gutzmer R, Utikal JS, Goppner D, et al. 2016 Neurological, respiratory, musculoskeletal, cardiac and ocular sideeffects of anti-PD-1 therapy. European Journal of Cancer $\mathbf{6 0} 210-225$. (doi:10.1016/j.ejca.2016.02.024)

Received in final form 28 June 2016

Accepted 2 August 2016

Accepted Preprint published online 2 August 2016
() 2016 Society for Endocrinology Printed in Great Britain
Published by Bioscientifica Ltd 